\title{
Carbon Isotopic Signature and Organic Matter Composition of Cenomanian High-Latitude Paleosols of Southern Patagonia
}

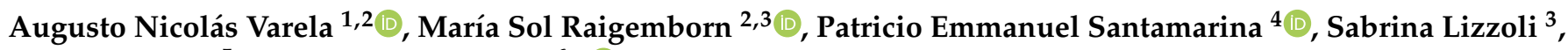 \\ Thierry Adatte ${ }^{5}$ and Ulrich Heimhofer ${ }^{6, *(\mathbb{D})}$ \\ 1 Y-TEC S.A., Consejo Nacional de Investigaciones Científicas y Técnicas (CONICET), Av. Del Petróleo s/n, \\ Berisso, Buenos Aires 1923, Argentina; augusto.n.varela@ypftecnologia.com \\ 2 Cátedra de Micromorfología de Suelos, Facultad de Ciencias Naturales y Museo, \\ Universidad Nacional de La Plata, Calle 122 y 60 s/n, La Plata 1900, Argentina; msolrai@gmail.com \\ 3 CONICET_UNLP, Centro de Investigaciones Geológicas, Diagonal 113 275, La Plata B1904DPK, Argentina; \\ sabrinalizzoli@gmail.com \\ 4 División Paleobotánica, Museo Argentino de Ciencias Naturales “Bernardino Rivadavia” (MACN-CONICET), \\ Av. Angel Gallardo 470, Buenos Aires C1405DJR, Argentina; santamarinape@gmail.com \\ 5 Institute of Geology and Paleontology, Université de Lausanne, 1015 Laussane, Switzerland; \\ thierry.adatte@unil.ch \\ 6 Institute of Geology, Leibniz Universität Hannover, 30167 Hannover, Germany \\ * Correspondence: heimhofer@geowi.uni-hannover.de
}

Citation: Varela, A.N.; Raigemborn, M.S.; Santamarina, P.E.; Lizzoli, S.; Adatte, T.; Heimhofer, U. Carbon Isotopic Signature and Organic Matter Composition of Cenomanian High-Latitude Paleosols of Southern Patagonia. Geosciences 2021, 11, 378. https:/ / doi.org/10.3390/geosciences 11090378

\section{Academic Editors: Jesus}

Martinez-Frias, Gregory A. Ludvigson, R. M. Joeckel and Marina B. Suarez

Received: 20 July 2021

Accepted: 1 September 2021

Published: 8 September 2021

Publisher's Note: MDPI stays neutral with regard to jurisdictional claims in published maps and institutional affiliations.

Copyright: (c) 2021 by the authors Licensee MDPI, Basel, Switzerland. This article is an open access article distributed under the terms and conditions of the Creative Commons Attribution (CC BY) license (https:/ / creativecommons.org/licenses/by/ $4.0 /)$.

\begin{abstract}
The Cenomanian Mata Amarilla Formation (MAF) in southern Patagonia $\left(\sim 55^{\circ} \mathrm{S}\right.$ paleolatitude, Austral-Magallanes Basin, Argentina) is composed mainly of stacked fluvial deposits with intercalated paleosols, which document Cenomanian environments at high-paleolatitudes in the Southern Hemisphere. We performed a multiproxy study of the paleosols and sediments of the MAF in order to (1) understand the composition of the soil- and sediment-derived organic matter (OM), (2) apply carbon isotope stratigraphy as a tool to correlate patterns obtained from the MAF with existing marine and non-marine $\delta^{13} C_{\text {org }}$ records worldwide, and (3) investigate the relationship between variations in spore-pollen assemblages of the MAF and the climatic conditions prevailing in the Cenomanian Southern Hemisphere. An integrated dataset was generated, including total organic carbon content, Rock-Eval pyrolysis data, stable isotope $\left(\delta^{13} \mathrm{C}_{\text {org }}\right)$ composition, and palynological data, combined with published paleosol-derived mean annual temperatures and mean annual precipitations. The results indicated that the OM preserved in the MAF paleosols allowed its use as a chemostratigraphic tool. The MAF $\delta^{13} \mathrm{C}_{\text {org }}$ curve showed the rather stable pattern characteristic for the Early to Late Cenomanian interval. The absence of the major positive carbon isotope excursion associated with oceanic anoxic event 2 provided an upper limit for the stratigraphic range of the MAF. The palynological data suggested the development of fern prairies during warmer and moister periods at the expense of the background gymnosperm-dominated forests. Overall, the multiproxy record provided new insights into the long-term environmental conditions during the Cenomanian in the high latitudes of the Southern Hemisphere.
\end{abstract}

Keywords: carbon isotopes; carbon cycle; terrestrial deposits; palynology; mid-cretaceous; Southern Gondwana

\section{Introduction}

The early Late Cretaceous (Cenomanian-Turonian; 100.5-89.4 Ma) was an interval characterized by exceptional warmth, caused by enhanced atmospheric $p \mathrm{CO}_{2}$ concentrations, probably related to elevated rates of continental fragmentation and increased oceanic crust production, together with the formation of large igneous provinces [1]. The pronounced greenhouse climate was marked by globally averaged mean annual temperatures (MATs) being $\sim{ }^{\circ} \mathrm{C}$ warmer than present day MATs [2-10]. Exceptionally warm temperatures and the acceleration of the hydrological cycle [11-15] led to increased primary 
productivity, causing oceanic anoxia [16,17], expressed in the widespread deposition of organic carbon-rich strata representing the so-called oceanic anoxic events (OAEs; [18-20]). Cretaceous OAEs are typically associated with relatively long-lasting positive and/or negative carbon isotope excursions (CIEs) in the range of several per mil (\%), which are interpreted to record shifts in the global carbon cycle $[6,19,21,22]$. The Mid-Cenomanian Event (MCE) and the Ocean Anoxic Event 2 (OAE2), which span the Cenomanian-Turonian boundary (ca. $94.1 \mathrm{Ma},[14,23,24])$, both show a distinct positive CIE well documented from marine successions worldwide [9,25-27]. The prominent CIE (3-4\%) associated with the OAE2 has also been documented in the carbon isotopic composition of land plantderived terrestrial organic matter $(\mathrm{OM})$ obtained from deep marine $[28,29]$ or paralic and continental strata $[30,31]$.

The MCE is a smaller-scale positive CIE (1-1.2\%) recorded in hemipelagic basins of the western Tethyan Sea, North and Tropical Atlantic Ocean [27,32-36] and in continental deposits from Japan $[37,38]$. Integrated astronomical age models from the Western Interior Seaway of North America date the onset of the MCE to $96.57 \pm 0.12 \mathrm{Ma}$, the peak of the MCE 1a at $96.49 \pm 0.15 \mathrm{Ma}$, and the end of the MCE to $96.36 \pm 0.12 \mathrm{Ma}[24,39,40]$.

Herein, we have presented total organic carbon (TOC) contents, Rock-Eval pyrolysis data and organic carbon isotope $\left({ }^{13} \mathrm{C}_{\mathrm{org}}\right)$ analyses of the sedimentary $\mathrm{OM}$ combined with palynological analyses from a Cenomanian high-latitude non-marine succession located in Southern Patagonia, Argentina. We discussed the composition of the soil-derived OM, as well as its preservation, decomposition and transformation in the different types of paleosols. We used carbon isotope stratigraphy as a tool to correlate patterns observed in the Cenomanian terrestrial $\delta^{13} C_{\text {org }}$ record from Patagonia, with published $\delta^{13} \mathrm{C}$ records from successions located in North America and Europe. Finally, we compared the organic geochemical and palynological data with published results of paleosol-derived MATs and mean annual precipitation (MAP) from the same succession in order to understand the relationship between variations in spore-pollen assemblages and the climatic conditions prevailing in the mid-Cretaceous Southern Hemisphere.

\section{Sedimentological-Paleopedological Context}

The Austral-Magallanes Basin is located on- and off-shore of the southernmost tip of South America (Argentina and Chile), in the area of southern Patagonia (Figure 1) and contains mainly siliciclastic deposits (e.g., [41,42]). The basin formed during two major phases including (i) a rift stage during the Early Cretaceous and (ii) a foreland stage during the Late Cretaceous and Cenozoic (e.g., [41,43]). In response to the regional change from an extensional towards a compressive regime, the Cardiel-Tres Lagos depocenter of the Austral-Magallanes Basin was infilled with estuarine-terrestrial deposits of the Mata Amarilla Formation (MAF) $[42,44,45]$. The paleolatitude of the study site is estimated at $\sim 55^{\circ} \mathrm{S}$ during the early Late Cretaceous [46].

The MAF crops out extensively in southwestern Santa Cruz Province (Figure 1) and is composed mainly of stacked fluvial deposits intercalated with paleosols $[8,44,47,48]$. The succession is characterized by an alternation of grey and black mudstones and thick white fine- to medium-grained sandstones $[47,48]$. Based on sedimentological observations and sequence stratigraphic analysis, the MAF was divided informally [48] into three units. The lower unit represents a coastal plain and lagoon environment, the middle one a fluvial meandering system, and the upper unit is characterized by more distal fluvial meandering/coastal plain deposits.

In the study area (Cerro Waring locality; Figures 1 and 2a), the MAF covers $\sim 125 \mathrm{~m}$ in thickness and the entire sequence is exposed (i.e., lower, middle and upper sections/units; [44]). The contact between the underlying Piedra Clavada Formation and the base of the MAF was assigned to the Albian-Cenomanian boundary ( 100 Ma; [44]) based on the occurrence of Mohria-like spores [49]. Recent $\mathrm{U} / \mathrm{Pb}$ radiometric age dates based on zircons from the uppermost Piedra Clavada Formation in the Cerro Waring locality constrain the age to $101 \pm 0.9 \mathrm{Ma}$ ([50]; Figure 2A). A U/Pb zircon age obtained from the middle section of 
the MAF gave an age of $96.23 \pm 0.71 \mathrm{Ma}$ (Middle Cenomanian; [44]; Figure 2A). The MAF succession at Cerro Waring was erosionally truncated by an unconformity surface. Above, the Campanian La Anita Formation was deposited, according to detrital zircon maximum depositional ages ([51-53]; Figure 2A).

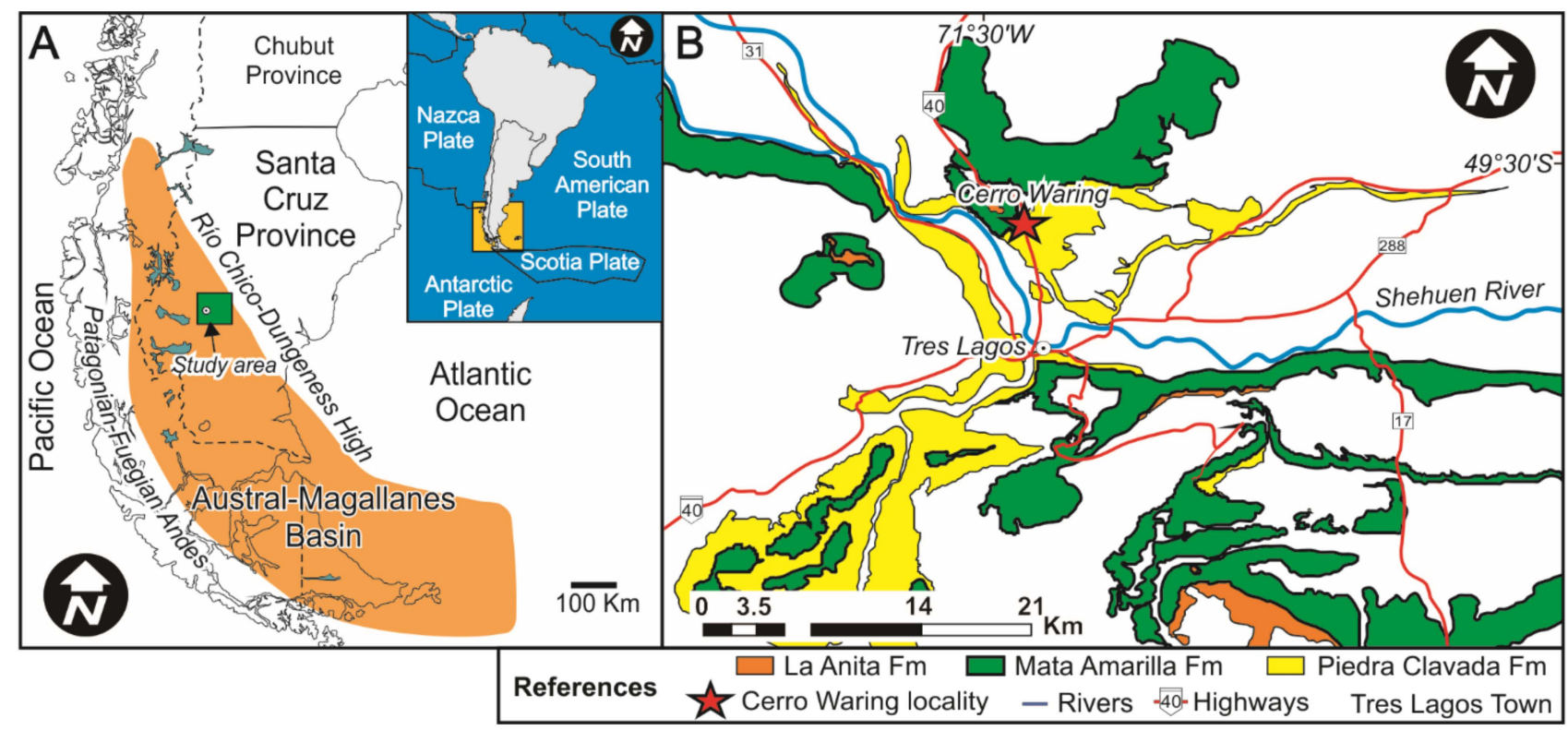

Figure 1. (A) Geological setting of the Austral-Magallanes Basin and location of the study area (green rectangle). (B) Geological map of the study area showing the mid-Cretaceous units and the study locality (modified from Varela et al., 2012a).

In the Cerro Waring area, the MAF contained a succession of stacked paleosols that showed a trend from Histosols and Vertisols in the lower section towards Vertisols, Inceptisols and vertic Alfisols in the middle section and finally ended with Histosols and Vertisols in the upper section ([8,44]; Figure 2A). Macro- and micromorphological analyses together with clay mineralogical, and geochemical data (Table 1) indicated that vertization (shrink-swell processes related to Vertisol formation), hydromorphism, clay illuviation, and bioturbation were the main pedogenic processes that took place in the MAF's paleosols [8]. Histosols (25\% of all paleosols in the measured sections) represent wetland paleosols (i.e., paleosols developed in lowland coastal areas) formed under impeded drainage conditions, which conditioned the hydromorphism that was the primary pedogenic process. Vertisols and Inceptisols (60 and 12\%, respectively) developed within the fluvial system and formed paleocatenas (i.e., Vertisols developed in proximal floodplain settings, and Inceptisols formed in distal floodplain areas). Although vertization constituted the main pedogenic processes in these Vertisols, hydromorphism was evident in both Vertisols and Inceptisols. Vertic Alfisols (3\%) exclusively developed right above the sequence boundary between the lower and the middle section of the MAF (Figure 2A), and were related to a forced regressive surface associated with the widespread preservation of a podocarp-dominated fossil forest over a vast area (more than $5400 \mathrm{~km}^{2}$ ) [54,55]. Clay illuviation and vertization were the principal pedogenic processes that formed the vertic Alfisol ([55]; Table 1). Paleosol features (see Table 1) and paleosol-derived climofunctions (see below) suggested that they developed under moderate hydrolysis and under a wide range of weathering conditions. The abiotic-based reconstructed climate was considered as subtropical temperate-warm and seasonally humid with MATs throughout the sequence averaging $12 \pm 2.1^{\circ} \mathrm{C}$, with mean annual precipitations (MAP) averaging $1404 \pm 108$ mm/yr [8]. Biotic (i.e., paleobotanical) proxies indicated similar climatic conditions [55-58]. 


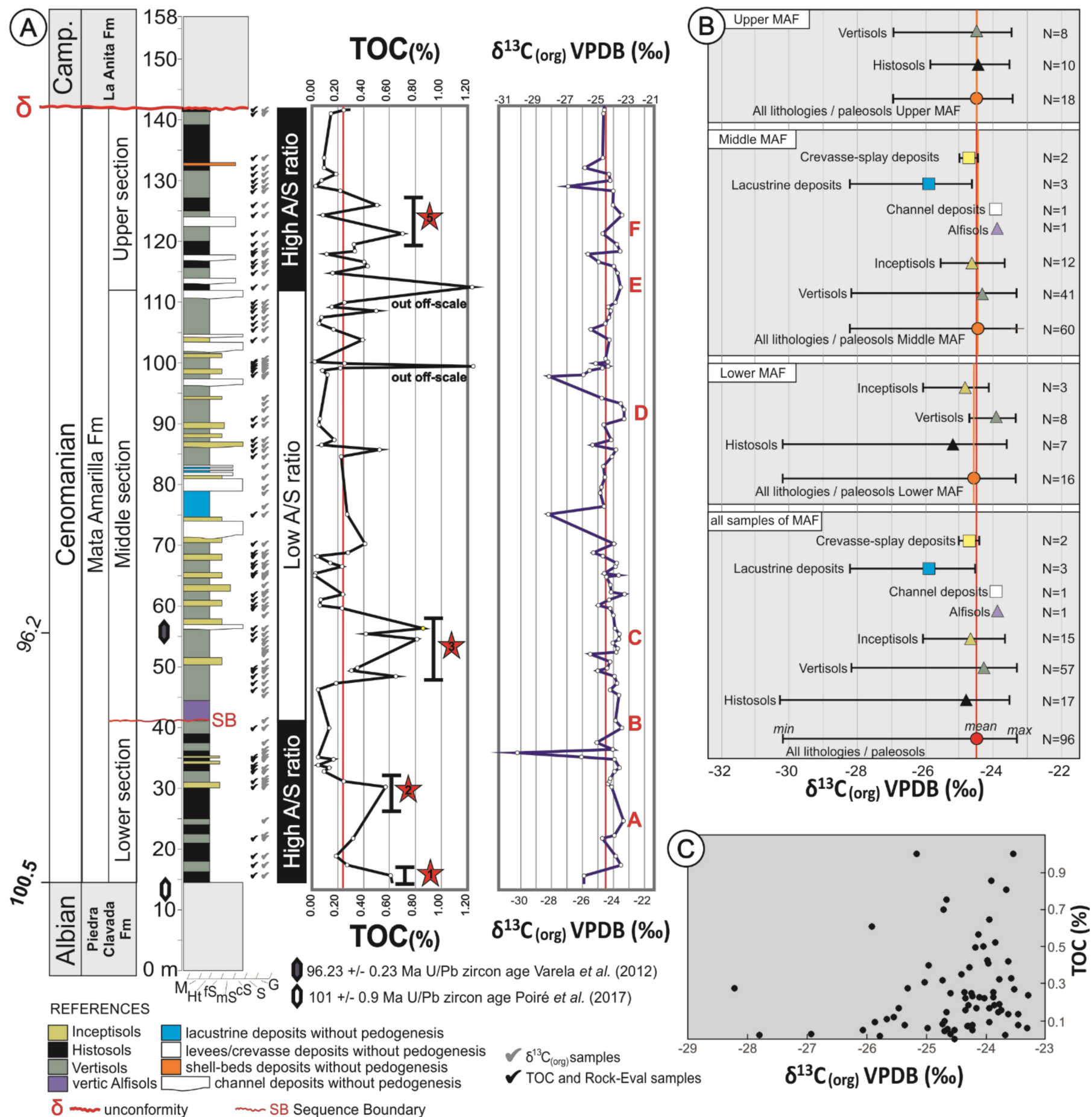

Figure 2. (A) Schematic sedimentary log of the Mata Amarilla Formation at Cerro Waring, showing the sedimentary facies and paleosol-types vertical distribution. Stratigraphic U/Pb zircon ages from Varela et al. (2012a) and Poiré et al. (2017). TOC content and $\delta^{13} \mathrm{C}_{\text {org }}$ composition of the Mata Amarilla Formation are shown with red lines representing the average values of TOC and $\delta^{13} \mathrm{C}_{\text {org }}$, respectively. Red stars indicate peaks or intervals characterized by increased TOC. Positive shifts $\delta^{13} C_{\text {org }}$ were labeled with the capital letters from " $\mathrm{A}$ " to " $\mathrm{F}^{\prime}$. (B) Mean, maximum and minimum $\delta^{13} \mathrm{C}_{\text {org }}$ values for the different lithostratigraphic intervals of the Mata Amarilla Formation. (C) XY-plot of $\delta^{13} C_{\text {org }}$ versus TOC values illustrating the lack of covariance. 
Table 1. Main macro- and micromorphological pedofeatures, clay-mineral assemblages, and geochemical data of the paleosols of the Mata Amarilla Formation. The coarse/fine-grained (c/f) related distribution terms: enaulic, porphyric, monic, gefuric and chitonic describe the spatial distribution of coarse grains and soil matrix. Birefringence fabric (b-fabric) of the paleosol matrix terms (undifferentiated and cross-striated) describe the orientation of the clay-minerals packages in the paleosol matrix.

\begin{tabular}{|c|c|c|c|c|}
\hline \multicolumn{5}{|c|}{ Main Pedofeatures and Compositional Data of the Paleosols of the Mata Amarilla Formation } \\
\hline Paleosol-Type & $\begin{array}{l}\text { Macromorphological } \\
\text { Pedofeatures }\end{array}$ & $\begin{array}{l}\text { Micromorphological } \\
\text { Pedofeatures }\end{array}$ & $\begin{array}{c}\text { Clay-Mineral } \\
\text { Assemblages (XRD } \\
\text { Analysis) }\end{array}$ & Geochemical Data \\
\hline Histosols & $\begin{array}{l}\text { Stacks of thin Oe-A-Bg } \\
\text { horizons, dark grey to } \\
\text { black mottles of } \\
\text { carbonaceous remains, } \\
\text { orange and purplish-blue } \\
\text { mottles, rhizoliths, } \\
\text { fossil roots }\end{array}$ & $\begin{array}{l}\text { Enaulic, close porphyric or } \\
\text { double space to open and } \\
\text { close porphyric c/f-related } \\
\text { distribution. Abundant } \\
\text { coarse organic components. } \\
\text { Undifferentiated b-fabric } \\
\text { disguised by Fe-oxides and } \\
\text { organic matter. } \\
\text { Simple-packing voids, } \\
\text { chambers, channels, and } \\
\text { plant residues. } \\
\text { Fe-Mn nodules }\end{array}$ & $\begin{array}{c}\text { S-P assemblage } \\
\text { (palygorskite-rich } \\
\text { association with } \\
\text { dominant smectite), >S-K } \\
\text { assemblage } \\
\text { (kaolinite-rich association } \\
\text { with smectite and other } \\
\text { clays), >S assemblage } \\
\text { (smectite-dominated } \\
\text { association) }\end{array}$ & $\begin{array}{c}\text { Average of } \mathrm{Al} / \text { bases } \\
\text { ratio: } 0.54, \mathrm{Ba} / \mathrm{Sr} \\
\text { ratio: } 1.05 ; \mathrm{Al} / \mathrm{Si} \\
\text { ratio: } 0.16 ; \mathrm{CIA}-\mathrm{K}: 79 \text {; } \\
\text { PWI: } 32\end{array}$ \\
\hline Vertisols & $\begin{array}{l}\text { Thick well-developed } \\
\text { profiles with A-Bss; } \\
\text { Btss-Bssg-Cg horizons, } \\
\text { greenish-gray matrix with } \\
\text { low chromas, slickensides, } \\
\text { angular peds, rhizoliths, } \\
\text { mottles, Fe-Mn nodules }\end{array}$ & $\begin{array}{c}\text { Double space to open } \\
\text { porphyric c/f-related } \\
\text { distribution. } \\
\text { Undifferentiated b-fabric } \\
\text { disguised by Fe-oxides and } \\
\text { organic matter or } \\
\text { cross-straited b-fabric. } \\
\text { Compound-packing voids, } \\
\text { chambers, channels, and } \\
\text { rhizoliths. Laminated and } \\
\text { non-laminated clay } \\
\text { coatings; Fe-Mn nodules }\end{array}$ & $\begin{array}{c}\text { S assemblage } \\
\text { (smectite-dominated } \\
\text { association), }>\text { S-K } \\
\text { assemblage } \\
\text { (kaolinite-rich association } \\
\text { with smectite and } \\
\text { other clays) }\end{array}$ & $\begin{array}{c}\text { Average of } \mathrm{Al} / \text { bases } \\
\text { ratio: } 0.54, \mathrm{Ba} / \mathrm{Sr} \\
\text { ratio: } 1.43 ; \mathrm{Al} / \mathrm{Si} \\
\text { ratio: } 0.17 ; \mathrm{CIA}-\mathrm{K}: 80 \text {; } \\
\text { PWI: } 35\end{array}$ \\
\hline Inceptisols & $\begin{array}{l}\text { Thin moderately to poorly } \\
\text { developed and stacked } \\
\text { profiles with A-Bw or } \\
\text { B/C-C horizons, poorly } \\
\text { developed horizonation, } \\
\text { gley colors, rhizoliths, } \\
\text { mottles, Fe-Mn nodules, } \\
\text { massive or poor ped } \\
\text { developments }\end{array}$ & $\begin{array}{l}\text { Gefuric to chitonic and } \\
\text { monic c/f-related } \\
\text { distribution. } \\
\text { Undifferentiated b-fabric. } \\
\text { Simple-packing voids and } \\
\text { chambers. Thin } \\
\text { non-laminated clay } \\
\text { coatings; Fe-Mn nodules }\end{array}$ & $\begin{array}{c}\text { S assemblage } \\
\text { (smectite-dominated } \\
\text { association) }\end{array}$ & $\begin{array}{l}\text { Average of } \mathrm{Al} / \text { bases } \\
\text { ratio: } 0.65, \mathrm{Ba} / \mathrm{Sr} \\
\text { ratio: } 1.67 ; \mathrm{Al} / \mathrm{Si} \\
\text { ratio: } 0.14 ; \mathrm{CIA}-\mathrm{K}: 76 \text {; } \\
\text { PWI: } 39\end{array}$ \\
\hline Vertic Alfisols & $\begin{array}{l}\text { Thick well-developed } \\
\text { profiles with A-A/E-Bt-Bss } \\
\text { horizons, dark gray co-lors, } \\
\text { well-structured Bt horizons } \\
\text { with prismatic peds and } \\
\text { Bss horizons with angular } \\
\text { peds, abundant cutans, } \\
\text { slickensides, mottles, } \\
\text { Fe-Mn nodules }\end{array}$ & $\begin{array}{l}\text { Monic, chitonic to double- } \\
\text { or simple-space porphyric } \\
\text { c/f-related distribution. } \\
\text { Undifferentiated or } \\
\text { cross-striated b-fabric. } \\
\text { Compound-packing voids, } \\
\text { channels, and rhizoliths. } \\
\text { Laminated to } \\
\text { microlaminated clay } \\
\text { infillings }\end{array}$ & $\begin{array}{c}\text { S assemblage } \\
\text { (smectite-dominated } \\
\text { association) }\end{array}$ & $\begin{array}{c}\text { Average of } \mathrm{Al} / \text { bases } \\
\text { ratio: } 0.51, \mathrm{Ba} / \mathrm{Sr} \\
\text { ratio: } 1.13 ; \mathrm{Al} / \mathrm{Si} \\
\text { ratio: } 0.20 ; \mathrm{CIA}-\mathrm{K}: 81 \text {; } \\
\text { PWI: } 37\end{array}$ \\
\hline
\end{tabular}

\section{Materials and Methods}

All samples were taken from $\sim 30 \mathrm{~cm}$ deep trenches in order to obtain fresh, nonweathered material and avoid contamination with modern organic carbon (OC) sources. A total of 97 bulk rock samples were collected, including all types of paleosols (with sampling fo- 
cusing on the B-horizons) and channel, crevasse splay and lacustrine deposits to determine the $\delta^{13} C_{\text {org }}$ of the sedimentary OC. In addition, TOC content measurements and Rock-Eval pyrolysis were carried out on 68 bulk samples derived from Histosols, Inceptisols, Vertisols, and lacustrine deposits. A total of 13 samples were processed for palynology and the spore-pollen assemblage was analyzed.

The sedimentary OM analysis was performed using a Rock-Eval 6 pyrolysis (Vinci Technology), available at the University of Lausanne, Switzerland, described in $[59,60]$. About 50-60 mg of sample powder was analyzed for each paleosols horizon and lacustrine deposit. The method is based on the stepwise pyrolysis and combustion of OM, releasing $\mathrm{CO}$ and $\mathrm{CO}_{2}$ gases monitored by a flame ionization detector (FID) for pyrolysis and an infrared detector (IR) for combustion under an artificial air supply $\left(\mathrm{N}_{2} \mathrm{O}_{2} 20 / 80\right)$. TOC content, Hydrogen Index (HI) and Oxygen Index (OI) were calculated by integrating the amounts of hydrocarbon compounds $(\mathrm{HC}), \mathrm{CO}$, and $\mathrm{CO}_{2}$ produced during thermal cracking of $\mathrm{OM}$ and oxidative decomposition of carbonate, between defined temperature limits $[59,60]$. Although 69 bulk samples of the MAF were analyzed, two of them were dismissed because TOC values were extremely high (29.77 and $27.38 \%$, respectively). These off-scale TOC values may reflect the presence of pieces of coal or large plant debris within the samples. On the other hand, samples with TOC contents below $0.11 \mathrm{wt} \%$ and OI higher than $500(n=26)$ exhibited poor reproducibility and consequently, they were excluded from further interpretation.

Measurements of $\delta^{13} C_{\text {org }}$ were carried out on decarbonated samples. Powdered samples were treated twice with $6 \mathrm{M} \mathrm{HCl}$ for $12 \mathrm{~h}$ to remove any carbonate phases and rinsed subsequently with deionized $\mathrm{H}_{2} \mathrm{O}$ until neutrality was reached. The $\delta^{13} \mathrm{C}$ composition of bulk OC was determined using an organic elemental analyzer (Thermo Scientific Flash 2000) connected online to a Thermo Fisher Scientific Delta V Advantage IRMS, available at the Leibniz University Hannover, Germany. The analytic accuracy and reproducibility are checked by replicate analyses of international standards (NBS 22). Reproducibility was better than $\pm 0.1 \%$ o for $\delta^{13} C_{\text {org }}$. Values are expressed in conventional delta notation relative to the Vienna-Pee Dee Formation belemnite (VPDB) international standard, in per mil (\%o).

For palynological analysis, rock samples were treated with $\mathrm{HCl}$ to remove carbonates and with HF for silicate removal. Residues were sieved, dehydrated with alcohol, and mounted in a UV-curable acrylate following procedures described by [61]. Strew mounts were investigated using a Leica DM500 transmitted light microscope and photographed with a Leica ICC50 HD camera. For palynomorph quantification, a minimum of 250 individual sporomorphs were counted (average 299 sporomorphs). The individual spore-pollen grains were assigned to floral groups according to their botanical affinity [62]. The stratigraphic frequency distribution of the palynomorphs is shown as a percentage of the total assemblage.

MAT proxies were calculated based on the salinization ratio (SAL) $(\mathrm{MAT}=-18,516(\mathrm{SAL})+17,298)$, where SAL $=(\mathrm{Na}+\mathrm{K}) / \mathrm{Al})$; and PWI (Paleosol Weathering Index) based $(\mathrm{MAT}=2.74 \ln (\mathrm{PWI})+21.39$, where PWI $=100 \times[(4.20 \times \mathrm{Na})+(1.66 \times \mathrm{Mg})$ $+(5.54 \times \mathrm{K})+(2.05 \times \mathrm{Ca})]$ [8]. MAP was calculated with different quantitative proxies. (i) MAP estimation based on $\Sigma$ Bases $/ \mathrm{Al}$ where $\mathrm{MAP}=-259.3 \ln (\Sigma \mathrm{Bases} / \mathrm{Al})+759$; (ii) MAP proxy based on the CIA-K index where MAP = 221.12e 0.0197(CIA-K); and (iii) MAP proxy based on the CALMAG index, where MAP = 22.69 (CALMAG)-435.8 [8].

\section{Results}

All organic geochemical analyses (including $\delta^{13} \mathrm{C}_{\mathrm{org}}, \mathrm{TOC}$, Rock-Eval pyrolysis), paleosol-derived geochemical climofunctions (MAT and MAP; [8]) and palynological investigations were carried out using the same bulk rock sample (see Figure 2) in order to provide a consistent data-set and to eliminate potential stratigraphic errors. 


\section{TOC and Rock Eval Pyrolysis}

The TOC content of the MAF deposits ranged from $0.02 \%$ to $0.81 \%$, with an average value of $0.22 \%$ (Figures $2 \mathrm{~A}$ and $3 \mathrm{~A}$ ). Samples of the same type of lithology showed considerable variability in TOC contents (see Figure 3A), suggesting significant heterogeneity of organic richness of the paleosols/sedimentary deposits. Lower mean TOC contents were recorded in Inceptisols samples, while highest mean TOC contents were observed in Histosols and lacustrine deposits (Figure $3 \mathrm{~A}$ ). The stratigraphic TOC trend across the MAF showed several intervals characterized by increased TOC (Figure 2a). In the lower part of the MAF (between 0 and $30 \mathrm{~m}$ ) there were two intervals ( 1 and 2 in Figure 2A) with TOC maxima reaching up to $\sim 0.60 \mathrm{wt}$. $\%$. In the middle section (between 45 and $60 \mathrm{~m}$ ) another interval was identified (interval 3 in Figure 2A) with TOC values of up to $0.81 \mathrm{wt}$. \% TOC. Finally, in the upper part of the section (between 105 and $130 \mathrm{~m}$ ) TOC content reached up to 0.70 wt. $\%$.
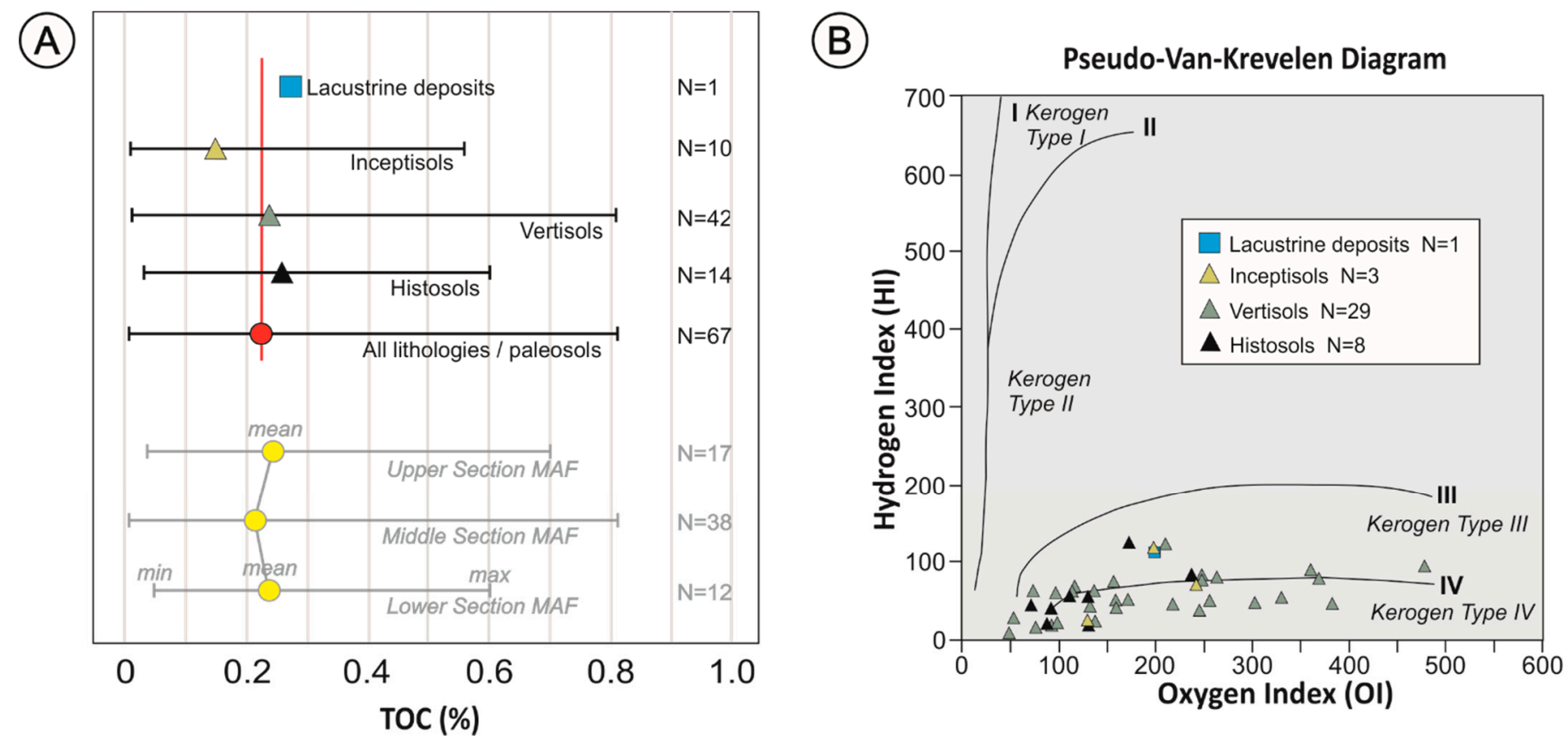

Figure 3. (A) TOC content (incl. mean, min. and max.) of the different paleosols and the lacustrine deposits of the Mata Amarilla Formation. Red line corresponds to the average TOC value of all analyzed lithologies. Lower part of diagram shows TOC content (incl. mean, min. and max.) of the different lithostratigraphic intervals. (B) Pseudo-Van-Krevelen Diagram $\left(\mathrm{HI}=\mathrm{mg} \mathrm{HC} / \mathrm{g}\right.$ TOC), vs. OI $=\mathrm{mg} \mathrm{CO}_{2} / \mathrm{g}$ TOC) showing a total of 39 samples with TOC values $>0.11 \mathrm{wt}$. \% and OI values $<500$, in order to illustrate the kerogen types obtained from the different paleosols and lithologies.

Rock-Eval pyrolysis of the kerogen yielded $\mathrm{HI}$ values ranging from 9 to $123 \mathrm{mg} \mathrm{HC} / \mathrm{g}$ TOC (avg. $73 \mathrm{mg} \mathrm{HC} / \mathrm{g}$ TOC), OI values ranging from 47 to $479 \mathrm{mg} \mathrm{CO} / \mathrm{g}$ TOC (avg. $178 \mathrm{mg} \mathrm{CO} / \mathrm{g} \mathrm{TOC}$ ), and $\mathrm{T}_{\max }$ values fluctuating from 400 to $601^{\circ} \mathrm{C}$ (avg. $452{ }^{\circ} \mathrm{C}$ ). $\mathrm{HI}$ and OI values showed certain variability between samples of the same type of paleosol (Figure 3B). The highest and lowest $\mathrm{HI}$ and OI values were recorded in Vertisols. The average HI value of Histosols ( 56), Vertisols $(\sim 53)$ and Inceptisols $(\sim 71)$ were close to the general average $(\sim 73)$ and lower than the HI value of the lacustrine deposits $(\sim 111)$. On the other hand, OI values of lacustrine strata $(\sim 198)$, and average values of Vertisols and Inceptisols ( 198 and $\sim 189$, respectively) were similar to the general OI average $(\sim 178)$. The average OI of Histosols ( 129) was lower.

The assessment of the kerogen type was based on a pseudo-Van-Krevelen diagram (Figure 3B). The sedimentary OM preserved in the MAF can predominantly be assigned to kerogen types III and IV (e.g., [63,64]). 


\subsection{Carbon Isotope Analysis}

The average $\delta^{13} \mathrm{C}$ composition of the sedimentary OM in the analyzed MAF succession was $-24.5 \%$, with values ranging from $-23.3 \%$ to $-30.2 \%$ (Figure $2 \mathrm{~A}$ ). The different sediment types and paleosols were all characterized by a rather similar average $\delta^{13} \mathrm{C}_{\text {org }}$ composition but showed differences in their isotopic variability (Figure 2B). Amongst paleosols, Inceptisols showed the smallest internal variability ( $-23.7 \%$ to $-26.1 \%$, avg. $-24.7 \%$ ) whereas Histosols showed a much larger scatter ( $-23.5 \%$ to $-30.3 \%$, avg. $-24.8 \%$ ). Vertisols showed moderate variation in their $\delta^{13} \mathrm{C}_{\text {org }}$ composition $(-23.3 \%$ o to $-28.2 \%$, avg. $-24.3 \%$ ). Alfisols ( $-23.8 \%$, single analysis) were less negative compared to the average pedogenic OM. The OM preserved in lacustrine deposits showed considerable variation $(-24.6 \%$ to $-28.2 \%$ ) and comparatively low values (avg. $-25.9 \%$ ). In contrast, crevasse-splay and channel deposits showed values of $-24.7 \%$ and $-23.9 \%$, respectively. The $\delta^{13} \mathrm{C}$ signature of the bulk OM did not show a covariance with TOC content (Figure 2C).

The stratigraphic $\delta^{13} \mathrm{C}_{\text {org }}$ trend was relatively stable throughout the succession, interrupted only by a few distinctive negative peaks (Figure $2 \mathrm{~A}$ ). Positive shifts ( $>1 \%$ above average) were labeled with capital letters from " $\mathrm{A}$ " to " $\mathrm{F}$ " (Figure 2A). The lower section of MAF showed a positive trend " $\mathrm{A}$ " $\left(1.1 \%\right.$ ) with maximum $\delta^{13} \mathrm{C}_{\text {org }}$ values reaching $-23.4 \%$ (at $25 \mathrm{~m}$ ), which was abruptly terminated by a distinct negative peak reaching values of $-30.2 \%$ (at $36 \mathrm{~m}$ ). The middle section of the MAF was characterized by positive trends "B" $(-23.4 \%$; at $40 \mathrm{~m})$ and " $\mathrm{C}$ " $(-23.6 \%$; at $55 \mathrm{~m})$, which coincided with the radiometric age of $96.23 \pm 0.71 \mathrm{Ma}$ [44]. This was followed by a negative peak $(-28.20 \%$ ) at $75 \mathrm{~m}$, which coincided with the onset of lacustrine strata. Then, values remained stable until the positive trend " $\mathrm{D}$ " $(-23.3 \%$, at $92 \mathrm{~m})$, which gave way to a negative peak $(-28.16 \%$, at $97 \mathrm{~m})$. The upper section of the MAF started with a positive shift "E" $(-23.5 \%$, at $103 \mathrm{~m})$, which was followed by a second positive shift " $\mathrm{F}$ " $(-23.6 \%$, at $118 \mathrm{~m})$. The uppermost part of the MAF ends with a negative peak $(-26.9 \%$, at $129 \mathrm{~m})$.

\subsection{Palynology}

The spore-pollen assemblage obtained from the MAF (Figure 4) was dominated by different pteridophyte spores (mainly Cyathidites sp., avg. 48.4\%), and pollen grains produced by Cheirolepidiaceae (Classopollis spp.; avg. 35.1\%). Other sporomorphs assigned to Bryophyta accounted for only $4.5 \%$ on average. Araucariaceae (Cyclusphaera ssp.) and Podocarpaceae (mainly Podocarpidites spp.) pollen grains also showed low values on average, with $5.5 \%$ and $3.8 \%$, respectively. Angiosperm pollen represented the smallest fraction of the assemblage, with an average of $2.6 \%$.

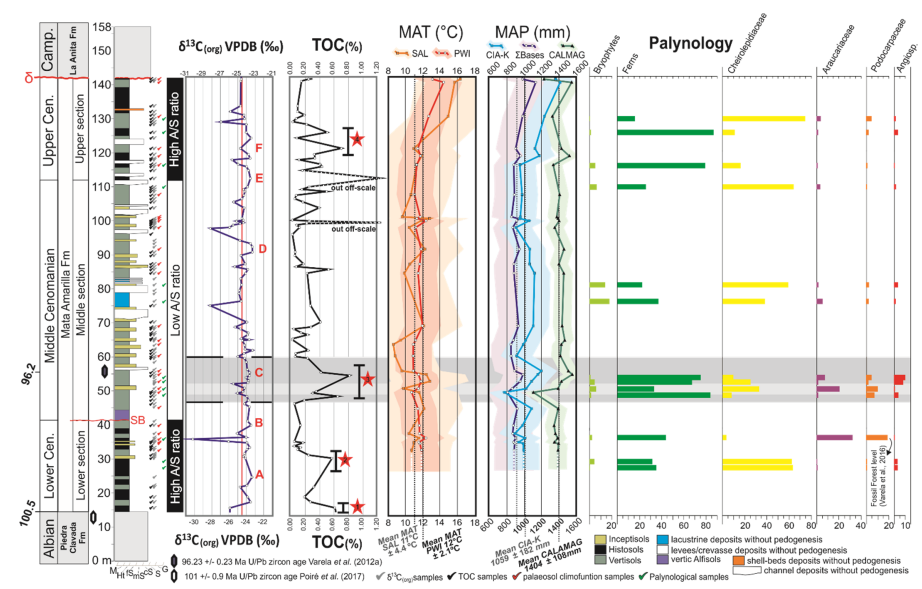

Figure 4. General stratigraphic scheme for the Mata Amarilla Formation showing organic geochemical data $\left(\delta^{13} \mathrm{C}_{\mathrm{org}}\right.$ and TOC), paleosol-derived geochemical climofunctions (MAT and MAP; Varela et al., 2018), and stratigraphic frequency distribution of the spores and pollen (in \% of the total assemblage). 
Cheirolepidiaceae pollen and fern spores showed opposing stratigraphic trends. When the Cheirolepidiaceae rose in abundance, ferns decreased in their proportions, and on the contrary, when the Cheirolepidiaceae receded, ferns showed high proportions (Figure 4). Podocarpaceae and Araucariaceae were more abundant in the uppermost lower section and the base of the middle section. In the upper half of the succession, the proportions of Podocarpaceae and Araucariaceae decreased significantly. Angiosperm proportions were low throughout the succession $(0.4-1.5 \%)$, with the highest proportion concentrated toward the base of the middle section (6.8-13.8\%) (Figure 4).

\section{Discussion}

\subsection{Composition of the Paleosol-Derived (and Sedimentary) Organic Matter}

The accumulation of OC in fossil soils was influenced by an array of preservation and degradation factors, including redox state as a primary control. Additionally, depth of the soil horizon, texture and type of horizon, clay mineralogy, sulfur content, abundance of amorphous mineral phases and diagenetic alteration were identified as important factors affecting the composition and distribution of OM in paleosols $[65,66]$. The dominant source of OC in soils is plant litter, microbial biomass and/or metabolites. Selective microbial decomposition of the more labile OM fraction results in OC loss and relative enrichment of the more recalcitrant compounds and particles in fossil soils (e.g., [67]). Compared to modern soil counterparts, paleosols contained only a fraction of the original soil OC due to burial decomposition [65].

Fossil soils developed in alluvial/fluvial depositional environments represent favorable settings for the storage of OC [66]. The MAF is composed of stacked fluvial deposits intercalated with abundant paleosols, which account for $81 \%$ of the total succession. Paleosol types represent Histosols, Vertisols, Inceptisols and subordinate vertic Alfisols, which formed under a temperate-warm, seasonally humid climate at a paleolatitude of $55^{\circ} \mathrm{S}[8,54]$.

The particulate OM observed in the MAF paleosols was essentially composed of translucent and opaque woody fragments, charcoal particles, and cuticle debris, as well as spores and pollen grains. The good preservation of the OM indicated that the level of diagenesis did not overprint the primary pedogenic signature. A well preserved palynological assemblage of the MAF was described by [58] with individual sporomorphs showing delicate wall ornamentation, which illustrated the overall good preservation state of the particulate $\mathrm{OM}$ fraction. The OM is considered to be mainly autochthonous in origin with only limited contribution from detrital OC inputs via eolian transport or from weathering/erosion of pre-Cretaceous strata in the hinterland. Average TOC content of $0.25 \%$ of the MAF paleosols are similar to Cenomanian paleosols from SW Japan, where the average TOC content is $0.2 \%$ [68], and Cenomanian paleosols of the Western Interior Basin (USA), where the average TOC is $<0.3 \%$ [31]. TOC content varies depending on paleosol type, with the highest average TOC contents of $0.26 \%$ observed in Histosols and interpreted to reflect attenuated burial decomposition due to soil formation under reducing and waterlogged conditions. In contrast, lower average TOC contents of $0.14 \%$ have been observed in Inceptisols, which represent weakly developed and poorly structured paleosols formed over relatively coarse textures in levees and crevasse-splay deposits under well drained conditions. Under such conditions, soil OM is more rapidly oxidized. Vertisols occur in the MAF in the form of moderately developed smectite-rich soils that formed under moderate to poor drainage conditions. Average TOC contents of $0.23 \%$ indicated preservation of a certain particulate OM fraction. All MAF paleosols showed strong variability in TOC contents, which may reflect the fragmentary preservation/fossilization of original surface-to-depth TOC gradients [65]. Additionally, lacustrine strata lacking pedogenesis was characterized by moderate TOC contents of $0.27 \%$, interpreted to reflect $\mathrm{OM}$ accumulation under predominantly oxic/dysoxic conditions.

Based on Rock-Eval pyrolysis, small-scale variations in HI and OI average values of the MAF paleosols were observed. Inceptisols showed, on average, slightly higher 
HI values ( 71) compared to other paleosols ( $\sim 53$ and 56 for Vertisols and Histosols, respectively). These relatively slightly high $\mathrm{HI}$ values could be due to the fact that the Inceptisols formed rapidly during a short time-span, which was not sufficient to allow the transformation of organics into humic and fluvic acids. Similarly, the moderate OI values of the Inceptisols ( 189) could reflect their formation over relatively coarse-textured sediments (i.e., levees and crevasse splay deposits) under well drained conditions [8], which allowed the rapid oxidation of the OM. These HI and OI values of the Inceptisols indicated that the kerogen essentially derived from land plants deposited under predominantly oxic conditions (Type III) and from refractory OM (Type IV) (e.g., [69]). Although Vertisols and Histosols presented similar HI average values, Vertisols showed a wider range compared to Histosols. Relatively low $\mathrm{HI}$ in the Vertisols is in agreement with their formation under shrinking and swelling of smectite clays, which allowed the transformation of OM into humic acids and, to a lesser extent, into fulvic acids. Meanwhile, low HI in Histosols attested to a low modification of organics. Vertisols showed the highest OI average value ( 198), which could be due to their formation under moderate-poor drainage conditions with subordinate oxidation during dry seasons [8]. Such conditions could have prevented the extensive oxidation of the OM that is reflected in high OI values. In the case of the Histosols, waterlogged conditions, typically of this paleosol type, were reflected in the lowest OI average values ( 129) of the MAF's paleosols. Subtle differences between Vertisols and Histosols can also be attributed to different analyzed horizons being organomineral (O or A horizons) in Histosols and mineral (B horizons) ones in Vertisols (e.g., [70]). In general, the low $\mathrm{HI}$ and the variable OI of the Vertisols and Histosols typically represent the kerogen Type IV, which is derived from refractory OM that may have been altered by subaerial weathering and/or microbial oxidation in swamps or soils (e.g., [63]). Kerogen Type IV with relatively low OI as those of the Histosols and some Vertisols reflects more anoxic conditions than soils with moderate-high OI (i.e., several Vertisols). However, a small population of Vertisols corresponded to kerogen Type III (e.g., [63,64]). The OM in the lacustrine deposits of the MAF came mainly from the fluvial system; small HI values may reflect a predominantly terrestrial origin, but it is possible that in situ production of algae could have contributed to the total sedimentary OM. In summary, all analyzed paleosols showed only minor variations in $\mathrm{HI}$ and $\mathrm{OI}$ values, indicating a similar OM composition throughout the MAF.

In general, no significant transformation of the primary plant-derived $\delta^{13} \mathrm{C}$ signature occurs during decomposition of plant litter and subsequent incorporation of organic byproducts into the soil OM pool [71]. Hence, the $\delta^{13} \mathrm{C}$ composition of soil OC was expected to predominantly reflect the isotopic signature of the original plant community contributing OC to the soil. The fluvial settings and coastal plains preserved in the MAF were covered by a conifer-dominated vegetation with a fern understory as indicated by palynological findings and by remnants of a podocarp-dominated fossil forest $[55,58]$. The overall average $\delta^{13} \mathrm{C}$ composition of paleosol-derived OM in the MAF was $-24.5 \%$, which corresponded well to reported values for mid-Cretaceous $C 3$ plant vegetation. Similar $\delta^{13} \mathrm{C}$ signatures have been reported for Cenomanian (pre-OAE2) fossil wood fragments derived from deep-water siliciclastics deposited along the NE and NW Pacific margin [29] as well as from time-equivalent bulk terrestrial (plant-derived) OM deposited in the Western Interior Basin [31]. The stratigraphic carbon isotope trend of the MAF was punctuated by several isolated negative $\delta^{13} C_{\text {org }}$ shifts reaching values as low as $-30.2 \%$. Such significantly depleted values in the bulk OM signature may indicate higher contributions from aquatic sources (i.e., algae) and/or incorporation of methanotrophs (i.e., organisms which consume isotopically negative methane; [72,73]), or marine-derived OM contribution in coastal plain environments [31]. Alternatively, the negative OM signature may reflect extreme aerobic microbial degradation in carbon-poor soils or might be related to closed canopy conditions and enhanced $\mathrm{CO}_{2}$ recycling in the understory [72-74]. An isolated negative peak at $75 \mathrm{~m}$ corresponded to lacustrine strata, which is often characterized by rather negative $\delta^{13} C_{\text {org }}$ signatures. 
However, based on more recent observations from modern soils and Cenozoic paleosols, [72] were able to demonstrate substantial $\delta^{13} \mathrm{C}$ fractionation during OC decomposition resulting in preferential enrichment of ${ }^{13} \mathrm{C}$ of up to $\sim 6 \%$ in the residual OC preserved. Despite the observed scatter in $\delta^{13} \mathrm{C}$ values obtained from the MAF paleosols, no values exceeding $-23.3 \%$ were observed, which contradicted strong fractionation due to progressive decomposition and ${ }^{12} \mathrm{C}$ removal. The absence of a clear relationship between paleosol TOC and $\delta^{13} \mathrm{C}$ values in the MAF (Figure 2C) did not support the idea of enhanced OC decomposition paralleled by ${ }^{13} \mathrm{C}$ enrichment. Visual and geochemical inspection provided no evidence for strong alteration of the $\delta^{13} \mathrm{C}$ signature during deep burial diagenesis since the overall preservation was good and the OM was thermally immature. In general, it is assumed that variations in $\delta^{13} \mathrm{C}$ signatures of plant/soil OC caused by ecological and physiological vital effects are averaged spatially due to incorporation of plant debris from various sources into floodplain sediments and soils [75]. The carbon isotope measurements from the MAF were independent of paleosol type and depositional environment, which demonstrated that the $\delta^{13} \mathrm{C}$ signature of pedogenic OC, although altered, was not strongly biased due to taphonomic/pedogenic processes. Therefore, isotopic analyses of bulk OC in the MAF deposits approximate the many-species average sample that best minimize physiological vital effect bias [75] and can serve as a tool to track changes in the global ocean-atmosphere $\delta^{13} \mathrm{C}$ reservoir.

\subsection{Comparison with Existing Marine and Terrestrial Carbon Isotope Records}

CIEs are widely used as stratigraphic markers and considered to record isotopic variations isochronous on a global scale [22,76]. Some major CIEs have been reported from both, marine and non-marine sedimentary successions, which indicates involvement of the entire ocean-atmosphere system (e.g., [31,77,78]). Common substrates used for carbon isotope studies in continental environments are pedogenic nodules, lacustrine or palustrine carbonates $[77,79,80]$ as well as fossil wood or other plant-derived particles [81-85]; meanwhile, bulk OC from terrestrial sediment or paleosol is less frequently used (e.g., $[79,86,87])$. Despite variations in absolute values and an often higher stratigraphic variability in terrestrial substrates, the overall trends and changes observed in marine reference curves are well reproduced in continent-derived $\delta^{13} \mathrm{C}$ records (e.g., $\left.[33,37,78]\right)$. Due to the lack of carbonate nodules or fossil wood particles in the paleosols of the MAF, and in order to obtain regularly spaced sampling throughout the studied succession, a $\delta^{13} C_{\text {org }}$ record based on bulk OM was established. The carbon isotope trend of the paleosol-derived OM elucidated a detailed chemostratigraphy for the Cenomanian stage of southernmost South America. The pattern visible in the $\delta^{13} \mathrm{C}_{\text {org }}$ record was independent of changes in lithology and not strongly affected by the type of paleosol or TOC content.

Detailed Cenomanian $\delta^{13} C_{\text {carb }}$ records have been established for certain parts of Europe, including those from the United Kingdom [32,88,89] and from the Vocontian Basin of SE France [90] which are regularly used as references in global comparisons [36]. The Early Cenomanian $\delta^{13} \mathrm{C}_{\text {carb }}$ trend from European records is characterized by a relatively stable pattern [25,32], which is replicated also in the $\delta^{13} C_{\text {org }}$ stratigraphic record obtained from the Western Interior Basin of North America [91]. Likewise, stable Early Cenomanian carbon isotope values have been reported from Japan [37,38] and from sections in Peru [92]. A similar stable pattern has been observed in the Lower Cenomanian part of the paleosolbased $\delta^{13} \mathrm{C}_{\text {org }}$ curve from southern Patagonia (Figure 5).

The stable Early Cenomanian $\delta^{13} \mathrm{C}$ global trend is terminated by a short-lasting, smallamplitude positive CIE located at the onset of the Middle Cenomanian at 96 Ma $[25,26,89]$. This so-called MCE [93] is recognized globally and typically composed of two closely spaced positive $\delta^{13} C$ peaks, MCE Ia and MCE Ib [26]. Although the MCE Ia is characterized by the occurrence of black shale deposits in ODP Leg 207 [94], it is not considered as an OAE. The MCE also differs from OAEs by its lower amplitude CIE of about $1 \%$ compared to about $3 \%$ for OAE2 [26,36]. The positive $\delta^{13} \mathrm{C}_{\text {carb }}$ anomaly of the MCE observed in Europe, North America and Asia is not well expressed in the MAF $\delta^{13} \mathrm{C}$ record. Its stratigraphic 
position can be approximately constrained based on the U-Pb age of $96.23 \pm 0.71 \mathrm{Ma}$ at $\sim 55 \mathrm{~m}$ [44]. The presence of two low-amplitude positive $\delta^{13} \mathrm{C}_{\text {org }}$ shifts " $\mathrm{B}^{\prime \prime}$ and " $\mathrm{C}^{\prime \prime}$ ( 0.9 and $1.8 \%$, respectively) may correspond to the reported $\delta^{13} \mathrm{C}_{\text {carb }}$ shifts of 0.8 and $1.2 \%$, which are associated with the MCE in sections of the English Chalk ([88]; Figure 5). Similarly, positive shifts in $\delta^{13} \mathrm{C}_{\text {org }}$ in the order of 0.9 and $1.2 \%$ have been recorded for the MCE in Japan ([37,38]; Figure 5). In a $\delta^{13} C_{\text {carb }}$ curve obtained from northern Peru, similar tendencies are displayed and have been assigned to the MCE [92].

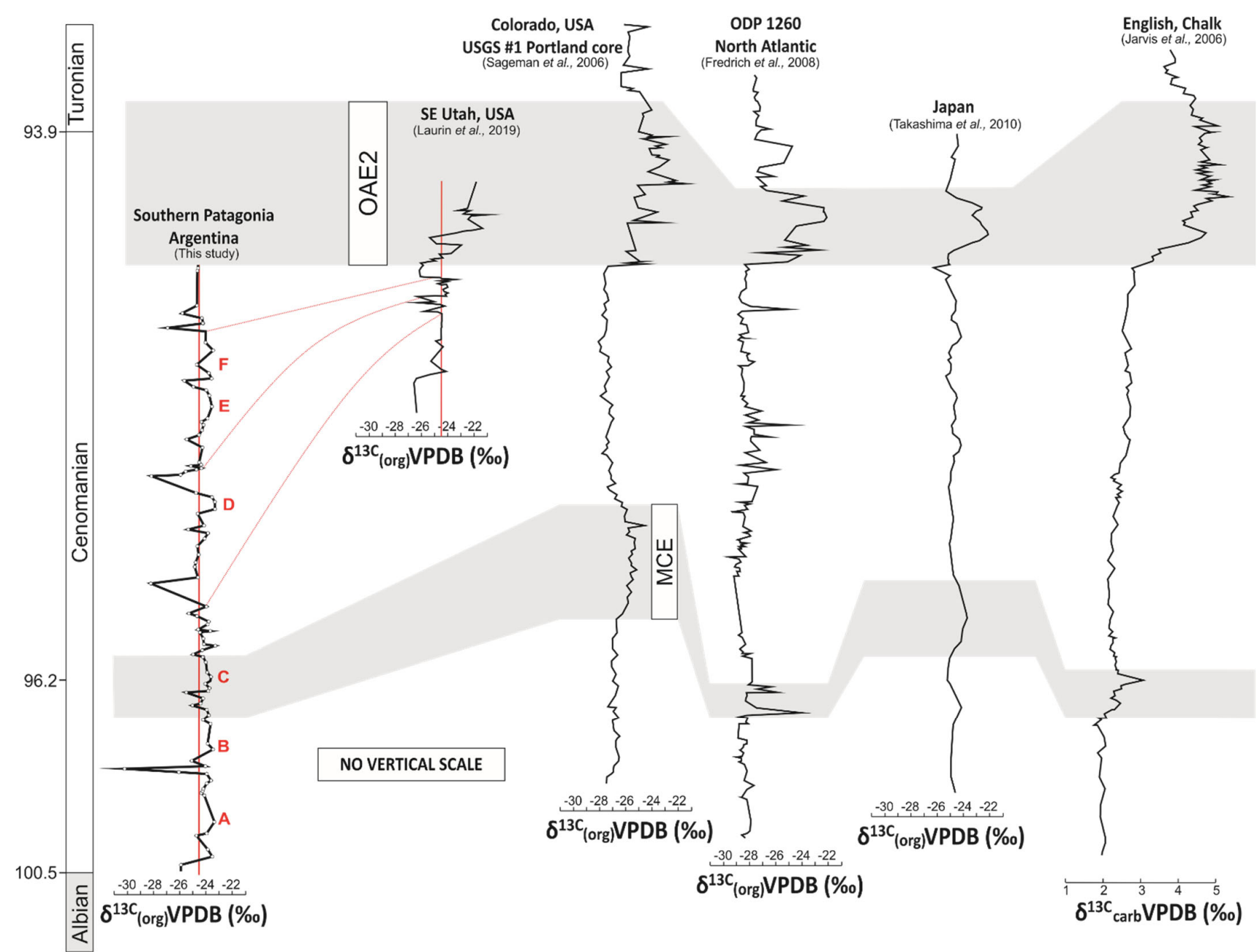

Figure 5. Chemostratigraphic comparison of the $\delta^{13} \mathrm{C}_{\text {org }}$ trends from the Mata Amarilla Formation with global reference carbon isotope curves from SE Utah, USA (Laurin et al., 2019); Colorado, USA (USGS \# 1 Portland core; Sageman et al., 2006); ODP 1260 North Atlantic (Friedrich et al., 2008); Japan (Takashima et al., 2010); UK (Jarvis et al., 2006). The positive carbon isotope anomaly of the Mid-Cenomanian Event in Europe, North America and Asia is tentatively positioned in the Mata Amarilla Formation based on an U-Pb age constraint of 96.23 $\pm 0.71 \mathrm{Ma}$. Red line represent potential correlation lines of similar $\delta^{13} C_{\text {org }}$ trends from the MAF and the terrestrial carbon isotope curve from SE Utah, USA (Laurin et al. 2019).

The absence of further geochronological data or of higher-resolving terrestrial biostratigraphy for the upper part of the studied section hampered any detailed stratigraphic correlations. However, when comparing the trends of the paleosol-derived $\delta^{13} \mathrm{C}$ record from southern Patagonia with global curves, some general statements can be made.

The remaining part of the Middle Cenomanian and the early Late Cenomanian showed a gentle increase in $\delta^{13} \mathrm{C}_{\mathrm{carb}}$, which abruptly gave way to the prominent positive CIE associated with OAE2 $[36,95]$. For the same interval, the $\delta^{13} C_{\text {org }}$ records showed a slightly different stratigraphic pattern, characterized by a stable or gradual trend toward more negative $\delta^{13} C_{\text {org }}$ values [34,36]. A significant and abrupt increase of carbon isotopes values ( 2-3\%o 
was the main characteristic feature of the OAE2 (e.g., [31,33,34,36,38,88,89,92,96,97] among others) and could be correlated in stratigraphic sections distributed worldwide (Figure 5). Comparisons of the $\delta^{13} C_{\text {org }}$ curve from southern Patagonia with high-resolution curves from North America, the equatorial Atlantic, Europe and Asia revealed the absence of the characteristic positive MCE and Late Cenomanian-Turonian CIE in the studied MAF (Figure 5).

The absence of the MCE and Late Cenomanian-Turonian CIE could be explained due to (i) a preservation issue, (ii) masking of the CIE due to changes on OM composition, or (iii) erosion/non-deposition. The pronounced CIE associated with the OAE2 has been recorded previously in various types of continent-derived substrates including fossil wood, terrestrial particulate OM and plant wax-derived $n$-alkanes [28,29,31,96,98]. This clearly illustrated that the carbon cycle perturbation associated with the Late Cenomanian-Turonian event did affect the entire ocean-atmosphere system, including the $\delta^{13} \mathrm{C}$ composition of atmospheric carbon species. Since the dominant source for $\mathrm{OM}$ in paleosols is plant-derived debris, a $\delta^{13} \mathrm{C}$ change in the order of several per mil (\%o) of atmospheric $\mathrm{CO}_{2}$ would be expected to be recorded in this type of substrate.

Changes in the composition of sedimentary bulk OM (e.g., change in the ratio of aquatic vs. land plant-derived $\mathrm{OM}$ ) can have a significant impact on its $\delta^{13} \mathrm{C}$ composition $[31,73,82]$. A local and persistent shift towards OC with a more negative carbon isotopic composition (e.g., [31]) could theoretically counterbalance the impact of a global positive anomaly. However, neither optical inspection nor RockEval pyrolysis results provided evidence for a major change in OM composition in the upper stratigraphic interval of the MAF.

The studied succession of the MAF in the Austral-Magallanes Basin was predominantly composed of nonmarine strata, essentially represented by fluvial siliciclastic alternating with paleosols $[8,44]$. Continental deposits are known to be highly fragmentary and prone to erosion; stratigraphic continuity cannot be expected (e.g., [99]). The top of the MAF is marked by an erosive unconformity, which forms the base of the Campanian deposits of the La Anita Formation ([51-53]; Figure 2A. This unconformity has been related to the foreland stage in the Austral-Magallanes Basin and the growth of the proto-Andes [100]. The absence of the Late Cenomanian-Turonian CIE in the MAF is best explained by non-deposition and/or post-depositional erosion due to regional tectonic activity [42,48].

From the comparison with the global curves, it was suggested that the uppermost part of the MAF would be restricted to the Upper Cenomanian, just before the onset of the OAE2 (Figure 5), generating a temporary stratigraphic constraint that was not available until now.

\subsection{The Mata Amarilla Formation as Environmental Archive}

Palynological data from the Lower Cenomanian of the MAF indicated a conifer forest dominated by Cheirolepideaceae with a lush understory composed of ferns and bryophytes (Figure 4). [101] proposed that the xeromorphic characteristics present in the leaves of Cheirolepidiaceae helped them to reduce loss through respiration and transpiration during the long periods of winter darkness in higher latitudes. These features would make the Cheirolepidiaceae the most suitable conifer group to flourish in the MAF, since the study area was located at $\sim 55^{\circ} \mathrm{S}$ paleolatitude during the Cenomanian, resulting in long and dark winters [8]. However, other factors must have affected the abundance of the Cheirolepidiaceae in the MAF (e.g., mean annual precipitation), since their abundances varied strongly throughout the succession (Figure 4). Subsequently, the Cheirolepidiaceae proportion decreased sharply and the proportions of ferns, Araucariaceae and Podocarpaceae rose. This type of vegetation is similar to the extensive open conifer-dominated forests developed in wet lowland areas under a warm climate described by [55] for the Middle Cenomanian of the MAF. Large forest glades resulted in multiple open spaces that were occupied mainly by ferns. 
During the early Middle Cenomanian, low abundances of gymnosperm pollen were accompanied by the highest fern spore and angiosperm pollen proportions recorded in the section. This could be interpreted as a reduction of the gymnosperm density, allowing the development of a fern prairie: a system dominated by ferns as thicket-forming plants (e.g., [102-104]). A strong drop in MAP values (from 1400 to $1100 \mathrm{~mm} /$ year) during this interval was coincident with a short-lasting decline in ferns and angiosperms and a modest recovery of gymnosperms (Figure 4). In the late Middle Cenomanian, the spore and conifer pollen proportions showed similar values compared to those recorded in the Early Cenomanian. During the early Late Cenomanian, alternating conditions may be suggested for the fluctuating proportions of ferns and Cheirolepidiaceae (Figure 4).

Throughout the section, there were two intervals interpreted to reflect the expansion of fern prairies at the expense of Cheirolepidiaceae-dominated forest: the early Middle Cenomanian and the early Late Cenomanian. Both intervals were associated with a similar rise in MAP values, but showed significant differences in the abundance of angiosperm pollen. The highest proportion of angiosperms was recorded during the early Middle Cenomanian $(6.8-13.8 \%)$, probably related to ideal conditions during this phase [35,94]. During intervals considered as climatic optima, the abundance and diversity of angiosperm pollen rose (e.g., [105-108]). Alternatively, besides climatic variations, changes in the depositional environment may also have affected the distribution of vegetation.

Ref [58] compared the palynoflora obtained from the MAF with existing mid- and high-latitude Albian-Turonian formations from the Southern Hemisphere (eastern and western Gondwana). These authors found that the Patagonian palynofloras showed different affinities depending on their paleolatitude. Palynofloras from high-latitude areas of Patagonia (MAF, Piedra Clavada/Kachaike formations ([57,58,109-117]) were related with Antarctica (Whisky Bay; [118,119]) and New Zealand (Tupuangi; $[120,121])$ palynofloras, based on the presence of widespread taxa, including Classopollis, Podocarpidites, Cyathidites, Microcachryidites, Tricolpites and Clavatipollenites. On the other hand, mid-latitude palynofloras from northern Patagonia (Cañadón Seco and Huincul formations; [122-125]) had similarities with Australian palynofloras (Toolebuc, Mackunda, Winton, Allaru and Bathurst Island formations; [126-129]). The reasons for this clustering are still unclear.

During the Late Cretaceous in the Northern Hemisphere, the Normapolles Province extended from southern and eastern North America (including northernmost Mexico) via Europe to West Siberia [130]. This palynological province was characterized by the abundance of angiosperm pollen grains assigned to the Normapolles complex, together with conifer-derived bisaccate and Classopollis pollen as quantitatively significant elements. Gleicheniaceae, Anemiaceae, and Matoniaceae are the most common spores found in those regions (e.g., [97,131-134]). However, higher latitude regions show a different microfloral composition during the Cenomanian, dominated by gymnosperms [135-138] and/or ferns $[139,140]$, with angiosperm pollen forming only a minor component. In this sense, the MAF palynoflora from Patagonia shows certain similarities with high-latitude Northern Hemisphere assemblages, but lacks the typical Normapolles elements.

\section{Conclusions}

1. This study provided a new detailed $\delta^{13} \mathrm{C}_{\text {org }}$ Cenomanian record for a continental sedimentary succession from southern South America.

2. The carbon isotope record from the MAF was largely independent of paleosol type and depositional environment, demonstrating that the $\delta^{13} \mathrm{C}$ signature of soil-derived OC was not strongly biased due to taphonomic/pedogenic processes.

3. Comparisons of the $\delta^{13} C_{\text {org }}$ curve of southern Patagonia with high-resolution trends from elsewhere in the world revealed the absence of the characteristic positive CIE expected to mark the Cenomanian-Turonian boundary. The absence of the CenomanianTuronian CIE was interpreted to reflect erosional processes and/or non-deposition as indicated by an unconformity surface at the very base of the overlying Campanian deposits of the La Anita Formation. 
4. The comparison of the $\delta^{13} C_{\text {org }}$ record, TOC values, and palynological data with paleosol-derived MAP provided a better understanding of the mid-Cretaceous climate/biota interaction in the Southern Hemisphere. During warmer and moister periods, fern prairies developed at the expense of the background conifer-dominated forest. Angiosperms formed only a minor component of the Cenomanian Southern Hemisphere high-latitude vegetation.

Author Contributions: Conceptualization, A.N.V., M.S.R., P.E.S. and U.H.; methodology, A.N.V., P.E.S.,.U.H. and T.A.; validation, A.N.V., M.S.R., P.E.S., and U.H.; formal analysis, A.N.V., M.S.R., P.E.S. and U.H.,; investigation, A.N.V., M.S.R., P.E.S. and U.H.; resources, A.N.V, M.S.R., P.E.S., T.A. and U.H; data curation, A.N.V, M.S.R., P.E.S., S.L., T.A. and U.H..; writing-original draft preparation, A.N.V, M.S.R., P.E.S., S.L., and U.H.; writing-review and editing, A.N.V, M.S.R., P.E.S., S.L., T.A. and U.H.; visualization, A.N.V., M.S.R., and U.H.; supervision, A.N.V., M.S.R., P.E.S. and U.H.; project administration A.N.V. and U.H.; funding acquisition, A.N.V. and U.H. All authors have read and agreed to the published version of the manuscript.

Funding: Agencia Nacional de Promoción Científica y Tecnológica (PICT 2012-0828 awarded to A.N. Varela), Subsidio Jóvenes Investigadores de la UNLP 2013 (La Plata University Exp. Cod. $100 \mathrm{~N}^{\circ}$ 19333/2/13 awarded to A.N. Varela), PIP 0259, PIP 0388, and PIP 0866 CONICET grants.

Acknowledgments: The authors would like to thank P. García, A. Iglesias, V. Barreda, the Secretaría de Cultura de la Provincia de Santa Cruz, Comisión de Fomento Tres Lagos, and Waring, Piccinini and Nacer families for their field work permission and priceless help both on and out the field. The authors would also like to thank $\mathrm{C}$. Wenske (LUH) for support with the stable isotope analyses and Sebastián Mirabelli, Carlos Jaramillo, and Orlando Cárdenas for their technical assistance with the palynological sample processing. Constructive comments by two expert reviewers improved this manuscript and are gratefully acknowledged.

Conflicts of Interest: The authors declare no conflict of interest.

\section{References}

1. Clapham, M.E.; Renne, P.R. Flood basalts and mass extinctions. Annu. Rev. Earth Planet. Sci. 2019, 47, 275-303. [CrossRef]

2. Barron, E.J. A warm equable Cretaceous: The nature of the problem. Earth-Sci. Rev. 1983, 19, 305-338. [CrossRef]

3. Arthur, M.A.; Dean, W.E.; Schlanger, S.O. Variations in the global carbon cycle during the Cretaceous related to climate, volcanism and changes in atmospheric $\mathrm{CO}_{2}$. In The Carbon Cycle and Atmospheric $\mathrm{CO}_{2}$ : Natural Variations Archean to Present; AGU Geophysical Monograph; Sundquist, E.T., Broecker, W.S., Eds.; American Geophysical Union: Washington, DC, USA, 1985; Volume 32, pp. 504-529.

4. Poulsen, C.J.; Pollard, D.; White, T.S. General circulation model simulation of the $\delta 18 \mathrm{O}$ content of continental precipitation in the middle Cretaceous: A model-proxy comparison. Geology 2007, 35, 199-202. [CrossRef]

5. Bodin, S.; Meissner, P.; Janssen, N.M.M.; Steuber, T.; Mutterlose, J. Large igneous provinces and organic carbon burial: Controls on global temperature and continental weathering during the Early Cretaceous. Glob. Planet. Change 2015, 133, 238-253. [CrossRef]

6. Jenkyns, H.C.; Dickson, A.J.; Ruhl, M.; Van Den Boorn, S.H.J.M. Basalt-seawater interaction, the Plenus cold event, enhanced weathering and geochemical change: Deconstructing oceanic anoxic event 2 (Cenomanian-Turonian, Late Cretaceous). Sedimentology 2017, 64, 16-43. [CrossRef]

7. O’Brien, C.L.; Robinson, S.A.; Pancost, R.D.; Sinninghe Damsté, J.S.; Schouten, S.; Lunt, D.J.; Alsenz, H.; Bornemann, A.; Bottini, C.; Brassell, S.C.; et al. Cretaceous sea-surface temperature evolution: Constraints from TEX86 and planktonic foraminiferal oxygen isotopes. Earth-Sci. Rev. 2017, 172, 224-247. [CrossRef]

8. Varela, A.N.; Raigemborn, M.S.; Richiano, S.; White, T.; Poiré, D.G.; Lizzoli, S. Late Cretaceous paleosols as paleoclimate proxies of high-latitude Southern Hemisphere: Mata Amarilla Formation, Patagonia, Argentina. Sediment. Geol. 2018, 363, 83-95. [CrossRef]

9. O'Connor, L.K.; Robinson, S.A.; Naafs, B.D.A.; Jenkyns, H.C.; Henson, S.; Clarke, M.; Pancost, R.D. Late Cretaceous temperature evolution of the southern high latitudes: A TEX86 perspective. Paleoceanogr. Paleoclimatol. 2019, 34, 436-454. [CrossRef]

10. Klages, J.P.; Salzmann, U.; Bickert, T.; Hillenbrand, C.D.; Gohl, K.; Kuhn, G.; Bohaty, S.M.; Titschack, J.; Müller, J.; Frederichs, T.; et al. Temperate rainforests near the South Pole during peak Cretaceous warmth. Nature 2020, 580, 81-86. [CrossRef] [PubMed]

11. Barron, E.J.; Hay, W.W.; Thompson, S. The hydrologic cycle. A major variable during Earth history. Palaeogeogr. Palaeoclimatol. Palaeoecol. 1989, 75, 157-174. [CrossRef]

12. White, T.; González, L.; Ludvigson, G.; Poulsen, C. Middle Cretaceous greenhouse hydrologic cycle of North America. Geology 2001, 29, 363-366. [CrossRef] 
13. White, T.; Witzke, B.; Ludvigson, G.; Brenner, R. Distinguishing base-level change and climate signals in a Cretaceous alluvial sequence. Geology 2005, 33, 13-16. [CrossRef]

14. Van Helmond, N.A.G.M.; Sluijs, A.; Reichart, G.-J.; Sinninghe Damsté, J.S.; Slomp, C.P.; Brinkhuis, H. A perturbed hydrological cycle during Oceanic Anoxic Event 2. Geology 2014, 42, 123-126. [CrossRef]

15. Ludvigson, G.A.; Joeckel, R.M.; Murphy, L.R.; Stockli, D.F.; González, L.A.; Suarez, C.A.; Kirkland, J.I.; Al-Suwaidi, A. The emerging terrestrial record of Aptian-Albian global change. Cretac. Res. 2015, 56, 1-24. [CrossRef]

16. Föllmi, K.B.; Weissert, H.; Bisping, M.; Funk, H. Phosphogenesis, carbon isotope stratigraphy, and carbonate-platform evolution along the Lower Cretaceous northern Tethyan margin. Geol. Soc. Am. Bull. 1994, 106, 729-746. [CrossRef]

17. Turgeon, S.; Brumsack, H.-J. Anoxic vs dysoxic events reflected in sediment geochemistry during the Cenomanian-Turonian Boundary Event (Cretaceous) in the Umbria-Marche Basin of central Italy. Chem. Geol. 2006, 234, 321-339. [CrossRef]

18. Schlanger, S.O.; Jenkyns, H.C. Cretaceous Oceanic Anoxic Events: Causes and Consequences. Geol. Mijnb. 1976, 55, 179-184.

19. Jenkyns, H.C. Cretaceous anoxic events: From continents to oceans. J. Geol. Soc. 1980, 137, 171-188. [CrossRef]

20. Jenkyns, H.C. Geochemistry of oceanic anoxic events. Geochem. Geophys. 2010, 11, 3. [CrossRef]

21. Robinson, S.A.; Heimhofer, U.; Hesselbo, S.P.; Petrizzo, M.R. Mesozoic climates and oceans - a tribute to Hugh Jenkyns and Helmut Weissert. Sedimentology 2017, 64, 1-15. [CrossRef]

22. Cramer, B.D.; Jarvis, I. Carbon Isotope Stratigraphy. In Geologic Time Scale; Gradstein, F.M., Ogg, J.G., Schmitz, M.D., Ogg, G.M., Eds.; Elsevier: Amsterdam, The Netherlands, 2020; Volume 1, pp. 309-343.

23. Meyers, S.R.; Siewert, S.E.; Singer, B.S.; Sageman, B.B.; Condon, D.J.; Obradovich, J.D.; Jicha, B.R.; Sawyer, D.A. Intercalibration of radioisotopic and astrochronologic time scales for the Cenomanian-Turonian boundary interval, Western Interior Basin, USA. Geology 2012, 40, 7-10. [CrossRef]

24. Eldrett, J.S.; Ma, C.; Bergmann, S.C.; Lutz, B.; Gregory, F.J.; Dodsworth, P.; Phipps, M.; Hardas, P.; Minisini, D.; Ozkan, A.; et al. An astronomically calibrated stratigraphy of the Cenomanian, Turonian and earliest Coniacian from the cretaceous Western Interior Seaway, USA: Implications for global cronostratigraphy. Cretac. Res. 2015, 56, 316-344. [CrossRef]

25. Voigt, S.; Gale, A.S.; Flögel, S. Midlatitude shelf seas in the Cenomanian-Turonian greenhouse world: Temperature evolution and North Atlantic circulation. Paleoceanography 2004, 19, PA4020. [CrossRef]

26. Forster, A.; Schouten, S.; Baas, M.; Sinninghe Damste, J.S. Mid-Cretaceous (Albian-Santonian) sea surface temperature record of the tropical Atlantic Ocean. Geology 2007, 35, 919-922. [CrossRef]

27. Hasegawa, T. Cenomanian-Turonian carbon isotope events recorded in terrestrial organic matter from northern Japan. Palaeogeogr. Palaeoclimatol. Palaeoecol. 1997, 130, 251-273. [CrossRef]

28. Takashima, R.; Nishi, H.; Yamanaka, T.; Hayashi, K.; Waseda, A.; Obuse, A.; Tomosugi, T.; Deguchi, N.; Mochizuki, S. Prevailing oxic environments in the Pacific Ocean during the mid-Cretaceous Oceanic Anoxic Event 2. Nat. Commun. 2011, 2, 234. [CrossRef] [PubMed]

29. Barclay, R.S.; McElwain, J.C.; Sageman, B.B. Carbon sequestration activated by a volcanic CO2 pulse during Ocean Anoxic Event 2. Nat. Geosci. 2010, 3, 205-208. [CrossRef]

30. Laurin, J.; Barclay, R.S.; Sageman, B.B.; Dawson, R.; Pagani, M.; Schmitz, M.; Eaton, J.; McElwain, J.C.; McInerney, F.A. Terrestrial and marginal marine record of the mid-Cretaceous Oceanic Anoxic Event 2 (OAE 2): High-resolution framework, carbon isotopes, CO2 and sea-level change. Palaeogeogr. Palaeoclimatol. Palaeoecol. 2019, 524, 118-136. [CrossRef]

31. Jenkyns, H.C.; Gale, A.S.; Corfield, R.M. Carbon- and oxygen-isotope stratigraphy of the English Chalk and Italian Scaglia and its palaeoclimatic significance. Geol. Mag. 1994, 131, 1-34. [CrossRef]

32. Sageman, B.B.; Meyers, S.R.; Arthur, M.A. Orbital time scale and new C-isotope record for Cenomanian-Turonian boundary stratotype. Geology 2006, 34, 125-128. [CrossRef]

33. Friedrich, O.; Erbacher, J.; Moriya, K.; Wilson, P.A.; Kuhnert, H. Warm saline intermediate waters in the cretaceous tropical Atlantic Ocean. Nat. Geosci. 2008, 1, 453-457. [CrossRef]

34. Andrieu, S.; Brigaud, B.; Rabourg, T.; Noret, A. The Mid-Cenomanian Event in shallow marine environments: Influence on carbonate producers and depositional sequences (northern Aquitaine Basin, France). Cretac. Res. 2015, 56, 587-607. [CrossRef]

35. Joo, Y.J.; Sageman, B.B.; Hurtgen, M.T. Data-model comparison reveals key environmental changes leading to CenomanianTuronian Oceanic Anoxic Event 2. Earth-Sci. Rev. 2020, 203, 103-123. [CrossRef]

36. Uramoto, G.-I.; Fujita, T.; Takahashi, A.; Hirano, H. Cenomanian (Upper Cretaceous) carbon isotope stratigraphy of terrestrial organic matter for the Yezo Group, Hokkaido, Japan. Isl. Arc 2007, 16, 465-478. [CrossRef]

37. Takashima, R.; Nishi, H.; Yamanaka, T.; Hayashi, K.; Waseda, A.; Obuse, A.; Tomosugi, T.; Deguchi, N.; Mochizuki, S. Highresolution terrestrial carbon isotope and planktic foraminiferal records of the Upper Cenomanian to the lower Campanian in the Northwest Pacific. Earth Planet. Sci. Lett. 2010, 289, 570-582. [CrossRef]

38. Batenburg, S.J.; De Vleeschouwer, D.; Sprovieri, M.; Hilgen, F.J.; Gale, A.S.; Singer, B.S.; Koeberl, C.; Coccioni, R.; Claeys, P.; Montanari, A. Orbital control on the timing of oceani anoxia in the Late Cretaceous, Discuss. Clim. Past. 2016, 12, 1995-2009. [CrossRef]

39. Scaife, J.D.; Ruhl, M.; Dickson, A.J.; Mather, T.A.; Jenkyns, H.C.; Percival, L.M.E.; Hesselbo, S.P.; Cartwright, J.; Eldrett, J.S.; Bergman, S.C.; et al. Sedimentary mercury enrichments as a marker for submarine large Igneous Province volcanism? Evidence from Mid-Cenomanian event and Oceanic Anoxic Event 2 (late cretaceous). Geochem. Geophys. 2017, 18, 4253-4275. [CrossRef] 
40. Biddle, K.; Uliana, M.; Mitchum, R., Jr.; Fitzgerald, M.; Wright, R. The stratigraphic and structural evolution of central and eastern Magallanes Basin, Southern America. In Foreland Basins; Allen, P., Homewoods, P., Eds.; Blackwell Scientific, Special Publication-International Association of Sedimentologists: New Jersey, NJ, USA, 1986; Volume 8, pp. 41-61.

41. Cuitiño, J.I.; Varela, A.N.; Ghiglione, M.C.; Richiano, S.; Poiré, D.G. The Austral-Magallanes Basin (Southern Patagonia): A synthesis of its stratigraphy and evolution. Lat. Am. J. Sedimentol. Basin Anal. 2019, 26, 155-166.

42. Arbe, H.A. Análisis estratigráfico del Cretácico de la Cuenca Austral. In Proceedings of the Geología y Recursos Naturales de Santa Cruz. Relatorio del Decimoquinto Congreso Geológico Argentino, El Calafate, Argentina, 23-26 April 2002 ; pp. $103-128$.

43. Varela, A.N.; Poiré, D.G.; Martin, T.; Gerdes, A.; Goin, F.J.; Gelfo, J.N.; Hoffmann, S. U-Pb zircon constraints on the age of the Cretaceous Mata Amarilla formation, southern Patagonia, Argentina: Its relationship with the evolution of the Austral basin Andean Geol. 2012, 39, 359-379. [CrossRef]

44. Varela, A.N.; Richiano, S.; D’Elia, L.; Moyano Paz, D.; Tettamanti, C.; Poiré, D.G. Sedimentology and stratigraphy of the Puesto El Moro Formation, Patagonia, Argentina: Implications for Upper Cretaceous paleogeographic reconstruction and compartmentalization of the Austral-Magallanes Basin. J.Soutg Am. Earth Sci. 2019, 92, 466-480. [CrossRef]

45. Van Hinsbergen, D.J.J.; De Groot, L.V.; van Schaik, S.J.; Spakman, W.; Bijl, P.K.; Sluijs, A.; Langereis, C.G.; Brinkhuis, H. A paleolatitude calculator for palaeoclimate studies. PLoS ONE 2015, 10, e0126946. [CrossRef] [PubMed]

46. Varela, A.N.; Richiano, S.; Poiré, D.G. Tsunami vs storm origin for shell bed deposits in a lagoon environment: An example from the Upper Cretaceous of Southern Patagonia, Argentina. Lat. Am. J. Sedimentol. Basin Anal. 2011, 18, 63-85.

47. Varela, A.N. Tectonic control of accommodation space and sediment supply within the Mata Amarilla Formation (lower Upper Cretaceous) Patagonia, Argentina. Sedimentology 2015, 62, 867-896. [CrossRef]

48. Archangelsky, S. Biogeographic implications of Albian Mohria-like spores (family Anemiaceae) in SW Gondwana (Patagonia). Rev. Palaeobot. Palynol. 2009, 157, 301-308. [CrossRef]

49. Poiré, D.G.; Iglesias, A.; Varela, A.N.; Richiano, S.; Mejía Ibañez, M.; Stroemberg, C. Edades U-Pb en Zircones de Tobas de la Fm. Piedra Clavada, Pcia. de Santa Cruz, Argentina: Un Marcador Albiano Tardio Para la Evolución Tectónica y Biológica de la Cuenca Austral. In Proceedings of the XX Congreso Geológico Argentino, Tucumán, Argentina, 7-11 August 2017.

50. Moyano Paz, D.; Tettamanti, C.; Varela, A.N.; Cereceda, A.; Poiré, D.G. Depositional processes and stratigraphic evolution of the Campanian deltaic system of La Anita Formation, Austral-Magallanes Basin, Patagonia, Argentina. Lat. Am. J. Sedimentol. Basin Anal. 2018, 25, 69-92.

51. Moyano Paz, D.; Richiano, S.; Varela, A.N.; Gómez Dacál, A.R.; Poiré, D.G. Ichnological signatures from wave- and fluvialdominated deltas: The La Anita Formation, Upper Cretaceous, Austral-Magallanes Basin, Patagonia. Mar. Pet. Geol. 2020, 113, 104168. [CrossRef]

52. Sickmann, Z.T.; Schwartz, T.M.; Graham, S.A. Refining stratigraphy and tectonic history using detrital zircón máximum depositional age: An example from the Cerro Fortaleza Formation, Austral Basin, southern Patagonia. Basin Res. 2018, 30, 708-729. [CrossRef]

53. Varela, A.N.; Veiga, G.D.; Poiré, D.G. Sequence stratigraphic analysis of Cenomanian greenhouse palaeosols: A case study from southern Patagonia, Argentina. Sediment. Geol. 2012, 271-272, 67-82. [CrossRef]

54. Varela, A.N.; Iglesias, A.; Poiré, D.G.; Zamuner, A.B.; Richiano, S.; Brea, M. Petrified forests in the Austral Basin marks a Cenomanian forced regression heterogeneous surface. Geobiology 2016, 14, 293-313. [CrossRef] [PubMed]

55. Iglesias, A.; Zamuner, A.B.; Poiré, D.G.; Larriestra, F. Diversity, taphonomy, and palaeoecology of an angiosperm flora from the Cretaceous (Cenomanian-Coniacian) in Southern Patagonia, Argentina. Palaeontology 2007, 50, 445-466. [CrossRef]

56. Santamarina, P.E.; Barreda, V.D.; Iglesias, A.; Varela, A.N. Salvinialean megaspores in the Late Cretaceous of southern Patagonia, Argentina. Acta Palaeontol. Pol. 2018, 63, 607-616. [CrossRef]

57. Santamarina, P.E.; Barreda, V.D.; Iglesias, A.; Varela, A.N. Palynology from the Cenomanian Mata Amarilla Formation, southern Patagonia, Argentina. Cretac. Res. 2020, 109, 104354. [CrossRef]

58. Lafargue, E.; Marquis, F.; Pillot, D. Rock-Eval 6 applications in hydrocarbon exploration, production, and soil contamination studies. Oil Gas Sci. Technol. 1998, 53, 421-437. [CrossRef]

59. Behar, F.; Beaumont, V.; Penteado, H.L.D.B. Rock-Eval 6 Technology: Performances and Developments. Oil Gas Sci. Technol. 2001, 56, 111-134. [CrossRef]

60. Noetinger, S.; Pujana, R.R.; Burrieza, A.; Burrieza, H.P. Use of UV-curable acrylates gels as mounting media for palynological samples. Rev. Del Mus. Argent. De Cienc. Nat. Nueva Ser. 2017, 19, 19-23. [CrossRef]

61. Raine, J.I.; Mildenhall, D.C.; Kennedy, E.M. New Zealand Fossil Spores and Pollen: An Illustrated Catalogue, 4th ed.; GNS Science Miscellaneous Series: Lower Hutt, New Zealand, 2011.

62. McCarthy, K.; Rojas, K.; Niemann, M.; Palmowski, D.; Peters, K.; Stankiewicz, A. Basic Petroleum Geochemistry for Source Rock Evaluation. Oilfield Rev. 2011, 23, 32-43.

63. Abbassi, S.; Edwards, D.S.; George, S.C.; Volk, H.; Mahlstedt, N.; di Primio, R.; Horsfield, B. Petroleum potential and kinetic models for hydrocarbon generation from the Upper Cretaceous to Paleogene Latrobe Group coals and shales in the Gippsland Basin, Australia. Org. Geochem. 2016, 91, 54-67. [CrossRef]

64. Broz, A.P. Organic matter preservation in ancient soils of Earth and Mars. Life 2020, 10, 113. [CrossRef]

65. Ferguson, B.; Lukens, W.E.; Masri, B.E.; Stinchcomb, G.E. Alluvial landform and the occurrence of paleosols in a humid-subtropical climate have an effect on long-term soil organic carbon storage. Geoderma 2020, 371, 114388. [CrossRef] 
66. Retallack, G.J. Interflag sandstone laminae, a novel sedimentary structure, with implications for Ediacaran paleoenvironments. Sediment. Geol. 2019, 379, 60-76. [CrossRef]

67. Lee, Y.W.; Lee, Y.I.; Hisada, K. Paleosols in the Cretaceous Goshoura and Mifune groups, SW Japan and their paleoclimate implications. Palaeogr. Palaeoclimatol. Palaeoecol. 2003, 199, 265-282. [CrossRef]

68. Mirzaloo, M.; Ghasemi-Nejad, E. Combined use of palynology and organic geochemistry in petroleum potential evaluation and paleoenvironmental interpretation of the Kazhdumi Formation (Aptian-Cenomanian) in the southwestern Zagros Basin, Iran. Geopersia 2012, 21, 27-40.

69. Masseroli, A.; Villa, S.; Mariani, G.S.; Bollati, I.M.; Pelfini, M.; Sebag, D.; Verrecchia, E.P.; Trombino, L. Reconsidering the compound effect of geomorphology, vegetation, and climate change on paleopedogenesis in sensitive environments (Northern Apennines, Italy). Catena 2021, 197, 104951. [CrossRef]

70. Nordt, L.C. Stable carbon and oxygen isotopes in soils. In Earth Sciences and Archaeology; Goldberg, P., Holliday, V.T., Ferring, C.R., Eds.; Springer: Boston, MA, USA, 2001; pp. 419-448.

71. Wynn, J.G. Carbon isotope fractionation during decomposition of organic matter in soils and paleosols: Implications for paleoecological interpretations of paleosols. Palaeogeogr. Palaeoclimat. Palaeoecol. 2007, 251, 437-448. [CrossRef]

72. Zhu, C.; Wagner, T.; Pan, J.-M.; Pancost, R.D. Multiple sources and extensive degradation of terrestrial sedimentary organic matter across an energetic, wide continental shelf. Geochem. Geophys 2011, 12, Q08011.

73. Graham, H.V.; Herrera, F.; Jaramillo, C.; Wing, S.L.; Freeman, K.H. Canopy structure in Late Cretaceous and Paleocene forests as reconstructed from carbon isotope analyses of fossil leaves. Geology 2019, 47, 977-981. [CrossRef]

74. Arens, N.C.; Jahren, A.H. Carbon Isotope Excursion in Atmospheric $\mathrm{CO}_{2}$ at the Cretaceous-Tertiary Boundary: Evidence from Terrestrial Sediments. Palaios 2000, 15, 314-322. [CrossRef]

75. Weissert, H.; Joachimski, M.; Sarnthein, M. Chemostratigraphy. Newsl. Stratigr. 2008, 42, 145-179. [CrossRef]

76. Cojan, I. Stable carbon isotope stratigraphy of the Paleogene pedogenic series of southern France as a basis for continental-marine correlation. Geology 2000, 28, 259-262. [CrossRef]

77. Gröcke, D.R.; Ludvigson, G.A.; Witzke, B.L.; Robinson, S.A.; Joeckel, R.M.; Ufnar, D.F.; Ravn, R.L. Recognizing the AlbianCenomanian (OAE1d) sequence boundary using plant carbon isotopes Dakota Formation, Western Interior basin, USA. Geology 2006, 34, 193-196. [CrossRef]

78. Maufrangeas, A.; Leleu, S.; Loisy, C.; Roperch, P.; Jolley, D.; Vinciguerra, C.; Nguyen-Thuye, O. Stratigraphy in Palaeocene continental sedimentary succession of the Northern Pyrenean Basin (Corbières, southern France) using 813 Corg isotopes. J. Geol. Soc. 2020, 177, 752-756. [CrossRef]

79. Raigemborn, M.S.; Krapovickas, V.; Zucol, A.F.; Zapata, L.; Beilinson, E.; Toledo, N.; Perry, J.; Lizzoli, S.; Martegani, L.; Tineo, D.E.; et al. Paleosols and related soil biota of the early Miocene Santa Cruz Formation (Austral-Magallanes Basin, Argentina): A multidisciplinary approach to reconstructing ancient terrestrial landscapes. Lat. Am. J. Sedimentol. Basin Anal. 2018, $25,117-148$.

80. Jahren, A.H.; Arens, N.C.; Sarmiento, G.; Guerrero, J.; Amundson, R. Terrestrial record of methane hydrate dissociation in the Early Cretaceous. Geology 2001, 29, 159-162. [CrossRef]

81. Heimhofer, U.; Hochuli, P.A.; Burla, S.; Andersen, N.; Weissert, H. Terrestrial carbon-isotope records from coastal deposits (Algarve, Portugal): A tool for chemostratigraphic correlation on an intrabasinal and global scale. Terra Nova 2003, 15, 8-13. [CrossRef]

82. Hesselbo, S.P.; Gröcke, D.R.; Jenkyns, H.C.; Bjerrum, C.J.; Farrimond, P.; Morgans Bell, H.S.; Green, O.R. Massive dissociation of gas hydrate during a Jurassic oceanic anoxic event. Nature 2000, 406, 392-395. [CrossRef]

83. Robinson, S.A.; Hesselbo, S.P. Fossil-wood carbon-isotope stratigraphy of the non-marine Wealden Group (Lower Cretaceous, southern England). J. Geol. Soc. 2004, 161, 133-145. [CrossRef]

84. Schneebeli-Hermann, E.; Kürschner, W.M.; Hochuli, P.A.; Weissert, H.; Bernasconi, S.M.; Roohi, G.; ur-Rehman, K.; Goudemand, N.; Bucher, H. Evidence for atmospheric carbon injection during the end-Permian extinction. Geology 2013, 41, 579-582. [CrossRef]

85. Hasegawa, T.; Pratt, L.M.; Maeda, H.; Shigeta, Y.; Okamoto, T.; Kase, T.; Uemura, K. Upper Cretaceous stable carbon isotope stratigraphy of terrestrial organic matter from Sakhalin, Russian Far East. A proxy for the isotopic composition of paleoatmospheric $\mathrm{CO}_{2}$. Palaeogeogr. Palaeoclimatol. Palaeoecol. 2003, 189, 97-115. [CrossRef]

86. Suarez, M.B.; Ludvigson, G.A.; González, L.A.; Al-Suwaidi, A.H.; You, H. Stable isotope chemostratigraphy in lacustrine strata of the Xiagou Formation, Gansu Province, NW China. Geol. Soc. Spec. Publ. 2013, 382, 143-155. [CrossRef]

87. Jarvis, I.; Gale, A.S.; Jenkyns, H.C.; Pearce, M.A. Secular variation in Late Cretaceous carbon isotopes: A new $\delta 13 C$ carbonate reference curve for the late Cenomanian-Campanian (99.6-70.6 Ma). Geol. Mag. 2006, 143, 561-608. [CrossRef]

88. Tsikos, H.; Jenkyns, H.C.; Walsworth-Bell, B.; Petrizzo, M.R.; Forster, A.; Kolonic, S.; Erba, E.; Premoli Silva, I.; Baas, M.; Wagner, T.; et al. Carbon-isotope stratigraphy recorded by the Cenomanian-Turonian oceanic anoxic event: Correlation and implications based on three key localities. J. Geol. Soc. 2004, 161, 711-719. [CrossRef]

89. Jarvis, I.; Lignum, J.S.; Gröcke, D.R.; Jenkyns, H.C.; Pearce, M.A. Black shale deposition, atmospheric $\mathrm{CO}_{2}$ drawdown, and cooling during the Cenomanian-Turonian Oceanic Anoxic Event. Paleoceanography 2011, 26, 3. [CrossRef]

90. Joo, Y.J.; Sageman, B.B. Cenomanian to Campanian Carbon Isotope Chemostratigraphy from the Western Interior Basin, U.S.A. J. Sediment. Res. 2014, 84, 529-542. [CrossRef] 
91. Navarro-Ramirez, J.P.; Bodin, S.; Immenhauser, A. Ongoing Cenomanian-Turonian heterozoan carbonate production in the neritic settings of Peru. Sediment. Geol. 2016, 331, 78-93. [CrossRef]

92. Coccioni, R.; Galeotti, S. The mid-Cenomanian Event: Prelude to OAE 2. Palaeogeogr. Palaeoclimatol. Palaeoecol. 2003, 190, 427-440. [CrossRef]

93. Friedrich, O.; Erbacher, J.; Wilson, P.A.; Moriya, K.; Mutterlose, J. Paleoenvironmental changes across the Mid Cenomanian Event in the tropical Atlantic Ocean (Demerara rise, ODP Leg 207) inferred from bentonic foraminiferal assemblages. Mar. Micropaleontol. 2009, 71, 28-40. [CrossRef]

94. Stoll, H.M.; Schrag, D.P. High-resolution stable isotope records from the Upper Cretaceous rocks of Italy and Spain: Glacial episodes in a greenhouse planet. Geol. Soc. Am. Bull. 2000, 112, 308-319. [CrossRef]

95. Heimhofer, U.; Wucherpfennig, N.; Adatte, T.; Schouten, S.; Schneebeli-Hermann, E.; Gardin, S.; Keller, G.; Kentsch, S.; Kujau, A. Vegetation response to exceptional global warmth during Oceanic Anoxic Event 2. Nat. Commun. 2018, 9, 1-8. [CrossRef]

96. Valle, B.; Dal' Bó, P.F.; Mendes, M.; Favoreto, J.; Rigueti, A.L.; Borghi, L.; Oliveira Mendonça, J.; Silva, R., Jr. The expression of the Oceanic Anoxic Event 2 (OAE2) in the northeast of Brazil (Sergipe-Alagoas Basin). Palaeogeogr. Palaeoclimatol. Palaeoecol. 2019, 529, 12-23. [CrossRef]

97. Kuypers, M.M.M.; Pancost, R.D.; Sinninghe Damsté, J.S. A large and abrupt fall in atmospheric $\mathrm{CO}_{2}$ concentration during Cretaceous times. Nature 1999, 399, 342-345. [CrossRef]

98. Miall, A.D. Fluvial Depositional Systems; Springer International Publishing: Berlin, Germany, 2014; Volume 14, p. 316.

99. Fosdick, J.C.; Romans, B.W.; Fildani, A.; Bernhardt, A.; Calderón, M.; Graham, S.A. Kinematic evolution of the Patagonian retroarc fold-and-thrust belt and Magallanes foreland basin, Chile and Argentina, 51 ${ }^{\circ} 30^{\prime}$ S. Geol. Soc.Am. Bull. 2011, 123, 1679-1698. [CrossRef]

100. Tosolini, A.M.P.; McLoughlin, S.; Wagstaff, B.E.; Cantrill, D.J.; Gallagher, S.J. Cheirolepideacean foliage and pollen from Cretaceous high-latitudes of southeastern Australia. Gondwana Res. 2015, 27, 960-977. [CrossRef]

101. Coe, M.J.; Dilcher, D.L.; Farlow, J.O.; Jarzen, D.M.; Russell, D.A. Dinosaurs and land plants. In The Origins of Angiosperms and Their Biological Consequences; Friis, E.M., Chaloner, W.G., Crane, P.R., Eds.; Cambridge University Press: New York, NY, USA, 1987; pp. 225-258.

102. Skog, J.E.; Dilcher, D.L. Lower vascular plants of the Dakota Formation in Kansas and Nebraska, USA. Rev. Palaeobot. Palynol. 1994, 80, 1-18. [CrossRef]

103. Collinson, M.E. "What use are fossil fern?" - 20 years on: With a review of the fossil history of extant Pteridophyte families and genera. In Pteridology in Perspective; Camus, J.M., Gibby, M., Jhons, R.J., Eds.; Kew, Royal Botanical Garden: Richmond, UK, 1996; pp. 349-394.

104. Jaramillo, C.; Rueda, M.J.; Mora, G. Cenozoic plant diversity in the Neotropics. Science 2006, 311, 1893-1896. [CrossRef]

105. Barreda, V.D.; Palazzesi, L.; Pujana, R.R.; Panti, C.; Tapia, M.J.; Fernández, D.A.; Noetinger, S. The Gondwanan heritage of the Eocene-Miocene Patagonian floras. J. S. Am. Earth Sci. 2021, 107, 103022. [CrossRef]

106. Fernández, D.A.; Palazzesi, L.; Estebenet, M.S.G.; Tellería, M.C.; Barreda, V.D. Impact of mid Eocene greenhouse warming on America's southernmost floras. Commun. Biol. 2021, 4, 1-9. [CrossRef]

107. Prebble, J.G.; Kennedy, E.M.; Reichgelt, T.; Clowes, C.; Womack, T.; Mildenhall, D.C.; Raine, J.I.; Crouch, E.M. A 100 million year composite pollen record from New Zealand shows maximum angiosperm abundance delayed until Eocene. Palaeogeogr. Palaeoclimatol. Palaeoecol. 2021, 566, 110207. [CrossRef]

108. Archangelsky, A.; Llorens, M. Palinología de la formación Kachaike, Cretácico Inferior de la Cuenca Austral, provincia de Santa Cruz. I- Esporas lisas y cinguladas. Ameghiniana 2003, 40, 71-80.

109. Archangelsky, A.; Llorens, M. Palinología de la Formación Kachaike, Cretácico Inferior de la Cuenca Austral, provincia de Santa Cruz. II. Esporas. Ameghiniana 2005, 42, 311-328.

110. Archangelsky, A.; Llorens, M. Palinología de la Formación Kachaike, Cretácico Inferior de la Cuenca Austral, provincia de Santa Cruz: Granos de polen de Gimnospermas. Ameghiniana 2009, 46, 225-234.

111. Barreda, V.; Archangelsky, S. The southernmost record of tropical pollen grains in the mid-Cretaceous of Patagonia, Argentina. Cretac. Res. 2006, 27, 778-787. [CrossRef]

112. Archangelsky, A.; Archangelsky, S.; Poiré, D.; Canessa, N. Registros palinológicos en la Formación Piedra Clavada (Albiano) en su área tipo, provincia de Santa Cruz, Argentina. Rev. Mus. Argent. Cienc. Nat. Nueva Ser. 2008, 10, 185-198. [CrossRef]

113. Archangelsky, S.; Archangelsky, A.; Cladera, G. Palinología y paleoambientes en el perfil de Bajo Comisión (Cretácico), provincia de Santa Cruz, Argentina. Rev. Mus. Argent. Cienc. Nat. 2012, 14, 23-39. [CrossRef]

114. Villar de Seoane, L.M.; Archangelsky, S. Taxonomy and biostratigraphy of Cretaceous megaspores from Patagonia, Argentina. Cretac. Res. 2008, 29, 354-372. [CrossRef]

115. Pérez Loinaze, V.S.; Archangelsky, S.; Cladera, G. Palynostratigraphic study of the Early Cretaceous Río Mayer and Kachaike formations at the Quebrada el Moro section, Austral Basin, southwestern Argentina. Cretac. Res. 2012, 34, 161-171. [CrossRef]

116. Pérez Loinaze, V.S.; Barreda, V.D.; Archangelsky, S.; Archangelsky, A. Cretaceous angiosperm pollen from the Kachaike formation, south-western Santa Cruz Province, Argentina. Hist. Biol. 2015, 28, 941-951. [CrossRef]

117. Dettmann, M.E.; Thomson, M.R.A. Cretaceous palynomorphs from the James Ross Island area, Antarctica-A pilot study. Br. Antarct. Surv. 1987, 77, 13-59. 
118. Keating, J.M.; Spencer-Jones, M.; Newham, S. The stratigraphical palynology of the Kotick Point and Whisky Bay formations, Gustav Group (Cretaceous), James Ross Island. Antarct. Sci. 1992, 4, 279-292. [CrossRef]

119. Mays, C.; Stilwell, J.D. Pollen and spore biostratigraphy of the mid-Cretaceous Tupuangi Formation, Chatham Islands, New Zealand. Rev. Palaeobot. Palynol. 2013, 192, 79-102. [CrossRef]

120. Mays, C. A Late Cretaceous (Cenomanian-Turonian) south polar palynoflora from the Chatham Islands, New Zealand. Mem. Assoc. Australas. Palaeontol. 2015, 47, 1-96.

121. Archangelsky, S.; Bellosi, E.S.; Jalfin, G.A.; Perrot, C. Palynology and alluvial facies from the mid-Cretaceous of Patagonia, subsurface of San Jorge Basin, Argentina. Cretac. Res. 1994, 15, 127-142. [CrossRef]

122. Vallati, P. Middle cretaceous microflora from the Huincul Formation ("dinosaurian beds") in the Neuquén Basin, Patagonia, Argentina. Palynology 2001, 25, 179-197.

123. Vallati, P. Las primeras angiospermas en el Cretácico de la Cuenca Neuquina (centro oeste de Argentina): Aspectos geológicos relacionados. Rev. Bras. Paleontol. 2006, 9, 83-92. [CrossRef]

124. Vallati, P. Paleotropical pollen grains from the Neuquén Group, Patagonia, Argentina. Carnets Géologie 2013, 11, 273-279. [CrossRef]

125. Burger, D. Palynological observations in the Carpentaria Basin, Queensland. Bur. Miner. Resour. Geol. Geophys. Aust. 1973, 140, 27-44.

126. Burger, D. Early Cretaceous angiosperms from Queensland, Australia. Rev. Palaeobot. Palynol. 1990, 65, 153-163. [CrossRef]

127. Burger, D. Early and middle Cretaceous angiosperm pollen grains from Australia. Rev. Palaeobot. Palynol 1993, 78, 183-234. [CrossRef]

128. Norvick, M.; Burger, D. Palynology of the Cenomanian of Bathurst Island. North. Territ. Austral. Bur. Miner. Resour. Geol. Geophys. 1975, 151, 1-237.

129. Herngreen, G.F.W.; Kedves, M.; Rovnina, L.V.; Smirnova, S.B. Cretaceous palynofloral provinces. A review. In Palynology, Principles and Applications; Jansonius, J., McGregor, D.C., Eds.; American Association of Stratigraphic Palynologists Foundation: Dallas, TX, USA, 1996; pp. 1157-1188.

130. Groot, J.J.; Penny, J.S.; Groot, C.R. Plant microfossils and age of the Raritan, Tuscaloosa and Magothy formations of the eastern United States. Palaeontogr. Abt. B 1961, 121-140.

131. Brenner, G.J. Early angiosperm pollen differentiation in the Albian to Cenomanian deposits of Delaware (USA). Rev. Palaeobot. Palynol. 1967, 1, 219-227. [CrossRef]

132. Hedlund, R.W. Palynology of the Red Branch Member of the Woodbine Formation (Cenomanian), Bryan County, Oklahoma; Oklahoma Geological Survey; University of Oklahoma: Norman, OK, USA, 1966; Volume 113, pp. 1-69.

133. Peyrot, D.; Barrón, E.; Comas Rengifo, M.J.; Barroso Barcenilla, F.; Feist-Burkhardt, S. Palinología del tránsito Cenomaniense/Turoniense en la sección de Puentedey (Burgos, España). Coloq. Paleontol. 2008, 58, 101-161.

134. Pierce, R.L. Lower Upper Cretaceous plant microfossils from Minnesota. Minn. Geol. Surv. 1961, 42, 1-86.

135. Galloway, J.M.; Sweet, A.R.; Pugh, A.; Schröder-Adams, C.J.; Swindles, G.T.; Haggart, J.W.; Embry, A.F. Correlating middle Cretaceous palynological records from the Canadian High Arctic based on a section from the Sverdrup Basin and samples from the Eclipse Trough. Palynology 2012, 36, 277-302. [CrossRef]

136. Sulphur, K. Quantitative Palynological Analyses of Albian-Cenomanian (Lower to Upper Cretaceous) Strata in the Sverdrup Basin: Insights into Paleoecology, Paleoclimatology and Palynostratigraphy. Master's Thesis, University of Calgary, Calgary, AB, Canada, 2015.

137. Peyrot, D.; Barrón, E.; Polette, F.; Batten, D.J.; Néraudeau, D. Early Cenomanian palynofloras and inferred resiniferous forests and vegetation types in Charentes (southwestern France). Cretac. Res. 2019, 94, 168-189. [CrossRef]

138. Žítt, J.; Nekvalisová, O.; Bosák, P.; Svobodová, M.; Stemproková-Jírová, D.; Stasstny, M. Rocky Coast facies of the CenomanianTuronian boundary interval at Velim (Bohemian Cretaceous Basin, Czech Republic). Second Part Věstník Státního Geol. Ust. 1997, 72, 141-155.

139. Svobodová, M.; Méon, H.; Pacltová, B. Characteristics of palynospectra of the Upper Cenomanian-Lower Turonian (anoxic facies) of the Bohemian and Vocontian Basins. Bull. Czech Geol. Surv. 1998, 73, 229-251.

140. Méon, H.; Guignard, G.; Pacltová, B.; Svobodová, M. Normapolles. Comparison between central and southwestern Europe during the Cenomanian and Turonian: Evolution of biodiversity and paleoenvironment. Bull. Soc. Géol. Fr. 2004, 175, 579-593. [CrossRef] 